\title{
THE LATERAL HOUSING DEVELOPMENT: CONDOMINIUM OR HOME OWNERS ASSOCTATION?
}

\author{
AARON M. SchreEBER $\dagger$
}

\section{The One Family-Communal Facility Housing Development}

The last few decades ${ }^{1}$ have witnessed the proliferation ${ }^{2}$ in the United States ${ }^{3}$ of housing developments containing individually owned homes as well as extensive communal facilities that are shared by all of the homeowners. The growth of this blend of private and communal housing has been spurred by many causes. Foremost is the flight to the suburbs of affluent home buyers. They have sought to escape the noise and overcrowding of the city by moving to bucolic areas near recreational facilities, where it would be possible to spend ever increasing amounts of leisure time. ${ }^{4}$ The shifting ethnic make-up of our cities ${ }^{5}$ has accelerated this exodus, and the restiveness and violence characteristic of inner city life today will undoubtedly add greater impetus to this outflow in the future.

Only a small portion of these home buyers could, however, afford to purchase a house complete with its own extensive recreational facilities

$\dagger$ Associate Professor of Law, University of Maryland. A.B. 1952, City University of New York. LL.B. 1955, Brooklyn Law School. IL.M. 1967, Yale Law School. Member, New York Bar. Formerly, Senior Attorney, New York State Attorney General's Condominium Theatre and Syndication Financing Bureau, 1962-1966.

1 Although the concept of common recreation areas was utilized as far back as the early 1800's in Louisberg Square, Boston, Massachusetts, and Grammery Park in New York City, it was not widely applied until the 1930's. See W. WHYTE, Cluster Developarent 37 (1964) [hereinafter cited as WHYTE].

2 Four hundred seventy such housing developments were studied by the Urban Land Institute and the results reported in URBAN LAND INSTITUTE, THE HoMrEs Assoctation HandBook, at vi, ix (1964) [hereinafter cited as HaNDBOoK]. See also Federal Housing Authority, Planned-Unit DeVelopment with a Homes AssociaTION 5 (1963) [hereinafter cited as BuLLETIN]; Krasnowiecki, Planned Unit Development: A Challenge to Established Theory and Practice of Land Use Control, 114 U. PA. L. REv. 47 (1965).

3 For a parallel increase of such housing in France, see Brown, French CoProperty of Apartments: A Model for English Law?, 110 SoL. J. 591, 615 (1966).

4 The facilities of these housing developments have ranged from unimproved open green acres, designed simply for strolling by adults and romping by children, to private golf courses and expensive structures furnished with varied and elaborate facilities and swimming pools. See WHYTE, supra note 1, at 92-111; HANDBOOK, supra note 2 , at 21 .

5 In New York City, the Negro population increased by more than 360,566 (47.2\%) between 1950 and 1960 , the Puerto Rican population by 366,268 (148.7\%), while the white population declined by 1,238,738. N.Y. CITY DEp'T of Comarerce \& Indus. Dev., 1964 Statistical Gurde for New York City 16. Similar changes have occurred in numerous other cities. 
and green areas. Accordingly, home builders, seeking to expand the market for their houses and to make them more salable, began to promote housing subdivisions featuring green belts, swimming pools, or other recreational and communal facilities in which use would be available for all who purchased homes in the developments. The cost of these added facilities to an individual home buyer was frequently moderate, since all shared in the expense of their erection and maintenance.

This type of housing complex was made more feasible by the practice of grouping houses more closely together on one portion of a tract and utilizing the land thus saved for common green areas and recreational facilities." This concept, commonly called "cluster housing," "planned unit development," or "density zoning," " reputedly enables builders to construct homes that are aesthetically appealing and yet cost less than homes built on conventional gridiron patterns which do not contain these additional common facilities. ${ }^{8}$ By bunching the homes on the portion of the land to be used for construction, and reserving the other areas for open space or recreation, the developer may also be able to construct more units than would otherwise be possible. ${ }^{9}$

Some communities, wanting to have green belts and more recreational facilities, and prepared to shift the burden onto the shoulders of home builders, have encouraged the construction of recreation-oriented cluster housing by the passage of the so-called "cluster-enabling acts." 10 These acts generally permit greater density of construction on a particular portion of a tract, where the balance is devoted to open space and communal facilities, as long as the overall density of the tract does not exceed municipal specifications.

The feasibility of constructing attractive one family homes by use of the cluster concept and newer techniques of construction, at a cost

6 See WнYтE, supra note 1 , at 11 .

7 See Bulletin, supra note 2, at 1.

3 See N. Norcross, Open Space Comaunities in the Market Place, (Urban Land Institute Tech. Bull. No. 57, 1966); BulleTIN, supra note 2, at 16 . Cost savings are alleged to result from the reduction in sizes required for building sites and in the reduced number of linear feet needed for street pavings, pipe, and sewers. In traditional developments, where the units are spread throughout a subdivision, the developer may be unable to erect some of the homes due to the unsuitable nature of the terrain, or because the tract is irregularly shaped, leaving insufficient space for the erection of particular units. It is claimed also that this type of home developments can outsell conventional homes. See WHYTE, supra note 1, at 16. A number of such developments offered in New York State during 1966 were sold out within a few days. Sales thereafter have met checkered market reactions.

9 See Whyte, supra note 1 , at 16, 23; Urban Land Institute, The Community Builders HandbooK 99 (1968); Kerr, Condominizm, 2 Proceedings ABA Real Property Probate and Trust Section 19, 24 (1965) [hereinafter cited as ProceedINGS]. This may result both in fuller exploitation of land resources and lowering of land costs per unit. In a similar vein, locating the homes on those portions of the tract most appropriate for building will reduce construction costs.

10 See Proceedrngs, supra note 9, at 24. 
which compares very favorably with multi-family housing, can bring closer to realization the goal of the Housing and Urban Development Act of 1968 and of the National Housing Act: ${ }^{11}$ to provide homes for moderate income groups which have heretofore been unable to afford to own their own homes. For a number of years the federal government has sought to encourage cluster housing by assisting in the development of prototypes and by providing counsel and advice to prospective developers. ${ }^{12}$

\section{A. Forms of Organization}

A variety of legal structures are currently employed throughout the United States in the ownership and management of such communalfacility housing developments. These structures run the gamut from tract associations, non-profit corporations, and co-operatives, which have been utilized for many decades, to condominiums. These have experienced a sharp upsurge in popularity, with thousands of units already built ${ }^{13}$ and in operation in this country, although they have only recently acquired legislative sanction ${ }^{14}$ and attention from American scholars. ${ }^{15}$ All too often, developers choose one of these forms of organization without carefully weighing their relative merits and pitfalls, and without examining alternative possibilities. Although much has been written on the use of associations, non-profit corporations, ${ }^{16}$ and condominiums for high-rise buildings ${ }^{17}$ there is a notable absence of studied analysis of the unique problems that confront developers and homeowners in con-

$11 \mathrm{McGraw}-\mathrm{Hill}$ Information Systems Company, A Study of Comparative Time and Cost for Building Five Selected Types of Low-Cost Housing (April, 1968). The goals of these acts are stated in 12 U.S.C.A. $\$ \S 1701 \mathrm{y}, 1715 z-2$ (a) (Supp. 1969).

12 Mortgage insurance is available pursuant to $\$ \S 203 \mathrm{~b}, 221,233$ and 234 of the National Housing Act, 12 U.S.C.A. $\$ \$ 1715 l(\mathrm{f}), 1715 l, 1715(\mathrm{x}), 1715(\mathrm{y})$. BulLetiN, supra note 2, at 17, 26. Encouragement for building new and more spacious communities is provided by the New Communities Act of 1968, 42 U.S.C.A. \$ 3901-14 (Supp. 1969). See Harrison, The FHA Condomininn: Use as a Means of Meeting the Need for Moderate Income Housing, 11 N.Y.L.F. 458 (1965) ; Welfield, The Condominimm and Median-Income Housing, 31 Fond L. REv. 457 (1963).

13 One authority has estimated that between 50,000 and 60,000 condominium units have been built in the past 6 years. Groswold, The Modern Concept of Condominitums, 47 Trtse News 89 (1968). Purchasers of condominiums in New York invested about 39 million dollars in 20 projects in 1966. Report of N.Y. Attorney General, N.Y. Times, Feb. 6, 1967, at 46, col. 1 .

14 Condominium statutes have been enacted in the District of Columbia and in all states except Vermont. The National Housing Act also covers condominiums. National Housing Act $\$ \$ 221,235$ (i) (B), 12 U.S.C.A. $\$ \$ 1715 l, 1715 z$ (Supp. 1969).

15 There are now 2 major treatises and form books dealing with condominiums: P. Rohan \& M. Reskin, 1 Real Estate Transactions (1968) and E. H. Breuer, Condominium (1962), in addition to more than 100 articles in legal journals.

16 See generally HANDBOOK, supra note 2; WHYTE, supra note 1.

17 For an excellent treatment of the problems of condominiums in general, see Berger, Condonininm, Shelter on a Statutory Foundation, 63 CoLum. L. Rev. 987 (1963). 
dominium subdivisions consisting of horizontally adjacent one-family homes with common facilities. Nor has there been sufficient inquiry as to whether the condominium form is at all appropriate for such lateral housing, or what its relative advantages and drawbacks are vis-à-vis other available legal formats. An attempt is made herein to explore these problems, suggest possible solutions, and examine the advantages and drawbacks of the condominium format as compared with incorporated and unincorporated tract associations.

\section{B. Overall Goals of Condominium Legislation}

An evaluation of the appropriateness of the condominium format and of the problems it raises for lateral housing subdivisions may be more effectively accomplished by comparing the objectives of the condominium approach with the results actually achieved under the present statutory framework. Condominium housing should be utilized by society to alter current practices and institutions regarding property, to remold our physical environment in order to achieve a more satisfactory and efficient utilization of land resources, and to bring about a more widespread distribution of economic wealth. Condominium legislation should be framed to help achieve these goals as completely as possible. More specifically, condominium legislation should encourage the extension of home ownership and privately owned recreational facilities of high quality to lower economic classes who cannot at present afford such homes or facilities. This should be accompanied by more efficient utilization of land resources and saving of space by use of devices such as cluster developments. The economic investment of unit purchasers must be protected by assuring the viability of the condominium organization and providing it with central management as well as the means to enforce its decisions and to deal with recalcitrant owners. The value of the homes (and, incidentally, their efficacy as a hedge against inflation) must be preserved along with the exclusive rights of all home owners to use and control the common areas until the condominium organization is terminated by mutual consent. At the same time, the home owners should be provided with income tax benefits similar to those available to owners of homes in conventional developments. Protection must be afforded in the event of destruction or termination of the organization, as well as insulation from liability in the event that anyone is injured in the common elements.

Purchasers of homes must also be given full and complete information regarding the advantages and drawbacks of the condominium format; and, at the same time, developers must be encouraged to construct such developments by being freed from unnecessary, onerous and 
time-consuming interference by governmental authorities. They must be permitted flexibility to plan the development and to alter plans as changing conditions may dictate, where such amendments will not unduly prejudice the interest of unit purchasers. The foregoing goals cannot be attained unless the housing is made attractive to mortgage lenders as well as to developers and purchasers, and unless adequate protection of investment is afforded to such mortgagees. Each unit owner should be insulated financially as much as possible from the failure of other owners to meet their obligations to the development or to pay taxes and mortgage debts.

Condominium statutes must also aim at an equitable allocation of power within the community. Since the resolutions and quality of management will affect the value of the units, a voice in the decisionmaking processes must be given to the developer during the period in which he is attempting to dispose of the remaining unsold units. The investments of mortgage lenders must also be protected against arbitrary or partisan decisions by the condominium organization. It is therefore essential that the right to vote and veto be apportioned fairly, and that the parties be permitted to work out other equitable arrangements to protect their interests.

If condominium legislation, together with more efficient construction and utilization of land resources, results in a decrease in the price of housing and makes it available to lower income groups who cannot presently afford homes, the involvement of these owners in the democratic processes inherent in group management can constitute an important educational achievement. ${ }^{18}$ Similarly, the financial experience and skills that they will acquire in dealing with mortgage lenders, paying taxes, managing their homes, reaping the benefits of wise management, and suffering financially by imprudence, can be another important by-product of the spread of lateral developments using the condominium form. Indeed, government financing of home purchases by the economically under-privileged may provide these persons with an incentive to maintain the homes and preserve their value, and may be far more advisable in the long run than the present system of public housing rented to the poor. ${ }^{19}$ While the lateral condominium may not be within the economic reach of the poor in large urban areas where land costs are high, it may have significant potential for the substantial number

18 See Quirk, Wein \& Gomberg, A Draft Program of Housing Reform-The Tenant Condomininm, 53 CoRnelt L. REv. 361 (1968). See also Welfeld, The Condominium and Median-Income Housing, 31 Ford L. REv. 457 (1963) ; Comment, Government Programs to Encourage Private Investment in Low Income Housing, 81 Harv. I. REv. 1295 (1968).

${ }^{19}$ See Quirk, Wein \& Gomberg, supra note 18 at 379-86. 
of poor in rural areas, in the smaller towns, and even in the suburban areas adjacent to large metropolises. ${ }^{20}$

Another important objective of condominium legislation should be the general well-being of unit purchasers. This objective includes encouraging erection of structurally sound and aesthetically beautiful developments with extensive recreational and cultural facilities, and their preservation by architectural controls. Thus condominium legislation could serve to increase the general well-being of groups in the lower economic strata by making available to them the comfort, conveniences, and status of home ownership and private recreational facilities, and, at the same time, to encourage the wise exploitation of land resources.

This Article undertakes to examine whether the condominium format, or the tract association (particularly the corporate form), is more appropriate to attainment of the aforementioned goals for lateral developments.

\section{Statutory Problems in Condominum Legislation for Lateral Housing Developments}

The first statute to deal with condominiums in the United States or its possessions was the Puerto Rico Act of $1958,{ }^{21}$ which was conditioned by the need to stimulate construction of condominium units in high-rise apartment buildings in crowded urban areas of Puerto Rico. ${ }^{22}$ As indicated by its title, "Horizontal Property Act," the Act envisaged high-rise structures divided horizontally into separate units, rather than into units separated solely by vertical planes. Accordingly, the Act specifies that it applies only to a project consisting of a "building" (in the singular) or "apartment house," 23 and it repeatedly refers to each unit as an "apartment" occupying all or part of a floor. ${ }^{24}$ None of these terms is appropriate for a group of distinct one-family structures horizontally adjacent to one another.

20 A very substantial proportion of the poor persons in the United States-possibly half of them-reside in rural areas. See U. S. DEp'T OF Agriculture, RuRAI PeOple in the AMrerican Economy, Agriculture Economic Report No. 101, 42 (1966); cf. U.S. Dep't of Healte, Education and Welfare, Soctal Security Bulletin, Mar. 1968; U.S. Dep't of Commerce, Statistical ABstracts of U.S. 339 (1967). 21 P.R. LAws ANN. tit. 31, §1291-1293(k) (Supp. 1968). This act considerably amplified earlier statutes sanctioning condominiums, such as the enabling statute passed in 1951. P.R. LAws ANN, tit. 31 \$ 1275 (Supp. 1968).

22 Kerr, Condoninium, A Preview 231, 235 (1962) [hereinafter cited as PrevIEw]; Kerr, Condominiums-Statutory Implementation, 38 Sr. JoHN's L. REv. 1, 4 (1963) [hereinafter cited as Statutory Implementation].

23 P.R. LAws ANN., tit. 31, §1291 (Supp. 1968); see Prevrew 251; Statutory Implementation 21.

24 E.g., id. $\$ 1291$ (a). "The term 'apartment' has come into use to designate the unit in a multi-unit structure under condominium whether residential, business, commercial or industrial. This is due, no doubt, to the translation of the SpanishAmerican apartamento into 'apartment.' The former has a much broader meaning than its English counterpart." Kerr, Will Condominizm Come to Connecticut?, 36 Conn. B.J. 481, 484 (1962). See also Prevrew, supra note 22, at 232. 
The passage of the Puerto Rico Act was followed by the enactment of section 234 of the National Housing Act of 1961. The United States Act, which was based upon the Puerto Rico model, ${ }^{25}$ originally authorized federal insurance for condominium mortgages only if the units were part of a "multi-family structure." No insurance was made available where the condominum project consisted of more than one structure. $^{26}$

The precedent set by these acts was followed by many of the states that subsequently enacted condominium laws. ${ }^{27}$ Some statutes expressly stated that they were applicable only to multi-unit structures, rather than to developments composed of separate one-family structures. ${ }^{28}$ Other statutes, while not clearly specifying their design for high-rise structures, indicate this intention by emulating the Puerto Rico Act in titling their statutes "Horizontal Property Act," and by repeatedly referring to the entire project as a "building" and to the units as "apartments." 20 at 1 .

${ }^{25}$ See PREVIEW, supra note 22, at 231; Statutory Implementation, supra note 22,

26 Housing Act of 1961, §104, 75 Stat. 160, 12 U.S.C. \$1715y (Supp. IV 1963). In 1964, the section catchline "Mortgage Insurance for Individually Owned Units in Multifamily Structures" was changed to "Mortgage Insurance for Condominiums." Act of Sept. 2, 1964, Pub. L. No. 88-560 $\$ 119$ (a) (1), amending 12 U.S.C. \$ 1715y (Supp. IV 1963) (codified at 12 U.S.C.A. $\$ 1715 y$ (1969)).

27 Many statutes are titled "Horizontal Property Act," or the equivalent. E.g., Alaska Stat. \$34.07.010 (Supp. 1968) ; ArIz. Rev. Stat. AnN. \$33-551 (Supp. 1969); ARK. STAT. ANN. \$ 50-1001 (Supp. 1967); D.C. CoDE ANAr. tit. 5 \$ 901 (1967); Hawam Rev. Stat. 514-1 (1967) ; Iowa Code Ann. § 499B-1 (Supp. 1969) ; Ky. Rev. Stat. \$381.805 (1962); N.J. STAT. ANN. \$46:8A-1 (Supp. 1968); VA. Code ANN. $\S 55-79.1$ (1969).

State legislation was spurred by the provisions of the National Housing Act which atthorized FHA insurance for condominium units only where the condominium project had the sanction of state law. 12 U.S.C.A. $\$ 1715 y(e)(1)$ (Supp. 1969). Despite the rush of the states to enact such condominium legislation, FHA mortgage insurance was in force for only 10 condominium projects consisting of 660 units as of Dec. 31, 1968. Division of Research \& Statistics, Federal Housing Authority, Condominium Housing Operations March 11, 1969.

28 E.g., "An Act Concerning the Ownership of Individual Units in Multi-Unit Structures," ILL. ANN. STAT. ch. 30 \& 301 (Smith-Hurd 1969) (1 Laws of I1l. 1120 (June 20,1963)). See also ArIz. Rev. Stat. ANN. \$§ 33-551 (1), (2) (Supp. 1969) (requires that each building contain more than one apartment but permits the use of more than one building); Colo. Rev. Stat. ANN. \$118-15-2 (1963) (defines unit as located in a multi-unit property but does not specify whether the property can include more than one building); D.C. CODE ANN. \$5-902(b) (1967); IowA CODE ANN. \$ 499B.2 (Supp. 1969) ; Kan. Stat. ANN. \$ 58-3102 (e) (Supp. 1969); Ky. Rev. Stat. $\$ 381.810$ (2) (1962) ; Minn. Stat. AnN. \$ 515.02(2), (6) (Supp. 1969); N.Y. Real PRop. LAw \& 339-e (1) (McKinney 1968); PA. Stat. ÁnN. tit. 68 \$ 700.102 (1) (1965); VA. CODE ANN. \$ 55-791.2(c) (1969).

29 E.g., ARK. STAT. ANN. $\$ \$ 50-1002($ a), (i) (Supp. 1967); Act of March 16, 1962, No. 750 \& 3 (a), [1962] S.C. Acts \& J. Res. 1866, as anended S.C. CoDE ANN. 57.495(a) (Supp. 1968).

The California statute refers to "apartment" and "building" (in the singular). CaI. Crv. Code $\$ 783$ (West Supp. 1969). However, CaL. Crw. CODE $\$ \$ 1350$ (3), 1351 (West Supp. 1969) refer to "structures" and "buildings" respectively.

The New York statute originally defined the term "building" as a "multi-unit building or buildings," Act of March 2, 1964, ch. 82 §339-e(1), [1964] 1 Laws of N.Y. 96, as amended N.Y. REAL Prop. LAw \$ 339-e(1) (McKinney 1968). Although the statute was amended in 1965 to include lateral projects, Act of July 2, 1965, ch. $727 \S 339-\mathrm{e}(1)$, [1965] 1 Laws of N.Y., amending Act of March 2, 1964, ch. 82 
It soon became apparent, however, that the condominium concept could be utilized for lateral housing, as well as high-rise structures. The National Housing Act was accordingly broadened in $1964^{\mathbf{3 0}}$ to authorize FHA mortgage insurance for detached one-family homes. ${ }^{31}$ This was accomplished by amending the Act to provide that it applied also to a one-family unit located in a "multi-family project" even if it was not a "multi-family structure." With few exceptions, however, most of the states that initially followed the statutory pattern of section 234 of the National Housing Act have not broadened their condominium statutes to include lateral housing.

A notable exception is New York State, ${ }^{32}$ where it was found that a large proportion of the condominium projects organized following passage of the Condominium Act of 1964 consisted of groups of one-family structures and garden apartments. ${ }^{33}$ The New York State Legislature thereupon followed the lead of the federal government and modified the statute to include single family homes by defining a condominium as "a group of buildings whether or not attached to each other." 34 The many benefits of the Act, including enforceability of

§339-e(1), [1964] 1 Laws of N.Y. 96 (1964) (codified at N.Y. REAL Prop. LAW $\$ 339-e(1)$ (McKinney 1968)), it nevertheless continues to refer repeatedly to entire condominium projects as a building. N.Y. REAL Prop. LAw $\$ 339-e(3)$ (b) ; 339-n (2), (3) \& (6); 339-cc (McKinney 1968).

30 Act of Sept. 2, 1964, Pub. L. No. 88-560, §119, amending 12 U.S.C. \$1715y (Supp. IV 1963) (codified at 12 U.S.C.A. $\$ 1715 y$ (1969)). See also Act of August 10, 1965 Pub. L. No. 89-117 \$1108, antending 12 U.S.C. $\$ \$ 1702,1703(f), 1706 \mathrm{c}$ $1709(\mathrm{k}), 1710,1713,1715,1739,1743,1744 \mathrm{f}, 1747,1748$ (1964) (codified in scattered sections of 12 U.S.C.).

31 See H.R. Rep. No. 1703, 88th Cong., 2nd Sess. 6 (1964) :

The existing law would also be amended to permit condominiums to consist of more than one structure; such as row apartments, a group of high-rise apartments, or a number of single family structures. . . .

32 See also Act of March 5, 1965, ch. 96, [1965] Laws of Ind. 135, anending Act of March 14, 1963, ch. 349, [1963] Laws of Ind. 878, (codified at IND. STAT. ANN. \$56-1202 (Supp. 1967)) ; N.M. STAT. ANN. \$70-4-2 (Cum. Supp. 1967); Act of April 6, 1966, ch. 683, [1966] Va. Acts \& J. Res. 1144, anending Act of April 3, 1962, ch. 627, [1962] Va. Acts \& J. Res. 1249, (codified at VA. Code ANN. §55-79.2 (1969) ) ; WIS. StaT. ANN. \$230.71 (Supp. 1969).

33 See Offering Plans of Hillcrest Park Condominium, Lawson Towne House, Leisure Village, Valley Towne Houses, Westchester Hills, and Elmwood Towne Houses. (The various Offering Plans cited in this Article are on file at the New York State Attorney General's Office, 80 Center Street, New York, New York.) See also Act of June 29, 1965, No. 212 [1965] Session Laws of Hawaii 329, annending HawaIr Rev. Stat. \$514-20 (1968) (authorizes condominium project to include 2 separate parcels of property separated by streets); Act of April 29, 1965, ch. $384 \$ 1,61$ Iowa Acts \& J. Res. 556 (1965), amending Act of March 15, 1963 ch. 293 \$2, 60 Iowa Acts \& J. Res. 381 (1963) (codified at Iowa Stat. Ann. \& 499B.2 (Supp. 1969) (permits a unit to occupy an entire building); PA. STAT. ANN. tit. $68, \S 700.102(1)$ (1965) (authorizes use of horizontal structures provided that each contain more than one unit).

34 Act of July 2, 1965, ch. 727 \&339-e [1965] Laws of N.Y., amending Act of March 2, 1964, ch. $82 \$ 339-e, 1$ Laws of N.Y. 96 (1964), (codified at N.Y. REAL Prop. LAW \$339-e (McKinney 1968)).

Apparently by an oversight the statute still states that it refers' to a "multi-lmit building or buildings." (emphasis added) Apparently, "multi-unit" refers only to "building." Where there is more than one building, these presumably do not have to be multi-unit structures. 
decisions and assessments of central management, equitable apportionment of maintenance costs and voting rights, and preservation of the common areas, were thus made available to all condominium developments, regardless of their physical format.

In the states that have not modified their condominium statutes to include one-family houses, ${ }^{35}$ these types of homes may be denied the benefit of condominium legislation. In other states, where statutes are tailored for high-rise developments, it is no surprise that these statutes are frequently inappropriate for lateral developments and impose needless limitations upon their effective use.

\section{Problems of the Developer}

\section{A. Requirements for Filing Building Plans and Completion of Units}

A developer of lateral housing commonly seeks to broaden the sales appeal of his homes by offering to construct them to order, in several different models. When homes are not constructed until they are purchased, the developer not only avoids the risk of constructing units that he may be unable to sell, but is also able to operate on a smaller capital investment. Instead of tying up money that would be required to construct all of the units planned for the development, the builder requires only enough funds to erect model homes and, perhaps, the first few units that are ordered. He can then utilize the proceeds from sales of these houses to construct other units as they are sold.

Another model of operation for laterals that has acquired popularity is construction of large housing developments in successive sections, each constructed only after the prior one has been completed and substantially sold out. ${ }^{36}$ In addition to reducing risks and capital needs, this method affords the builder the option to plat and develop only a portion of a tract. Thus the remainder of the tract is protected from the imposition of higher realty taxes, or the creation of easements and dedication of the common areas planned thereon, ${ }^{37}$ which may follow platting an entire tract.

Neither method of development is feasible, however, unless a developer is permitted to construct and convey some of the homes in the

35 It may be argued that even where the statutes clearly relate only to multi-unit structures, lateral projects may, perhaps, qualify if the units are all attached to one another and all are viewed as part of one multi-unit lateral structure. Although common law condominiums which do not utilize the statutory protection may be organized, they face many difficulties. P. RoHAN \& H. RESKrN, supra note $15, \$ 4.01$ at 4-1 (1968). See also Schwartz, Condominimin: $A$ Hybrid Castle in the Sky, 44 B.U. L. REv. 137, 139-47 (1964).

36 See BulleTIN, supra note 2, at 21; HANDBook, supra note 2, at 214-21; J. Krasnowiecki, Legal Aspects of Planned Unit Residential Developarent 50-59 (Urban Land Institute Tech. Bull. 52, 1965).

37 See J. KRASNOWIECKI, supra note 36 , at 51 . 
complex before the additional units are sold or even take final design. It is precisely this flexibility which is seriously obstructed by existing condominium legislation.

In many states no condominum units may be conveyed until all are constructed $^{38}$ or until final, detailed building plans and specifications are filed for all units. ${ }^{39}$ Even when filing plans for all units is dispensed with in order to convey any one home, filing may be a condition precedent to forming the condominium organization and putting it into operation. ${ }^{40}$ Since conveyance of a unit is senseless if the condominium organization is not functioning and the statutory provisions are not yet applicable, the practical effect of such statutes is that no unit can be conveyed unless plans are first drawn up and filed for all units.

The purported purpose of these requirements is to inform unit purchasers of the size and other important aspects of the development and to assure them that it will be completed. This may not be unduly harsh where the development consists solely of one high-rise building, since once final plans are drawn for one unit, they may limit the size and effect the location of other units on the same floor. It is therefore likely that when a few units on one story of the proposed building have been sold, rough plans will be feasible for the remaining units. Certainly, construction of any unit cannot be completed without at the same time completing vital components of the building, such as the outer walls, foundations and the roof, which are required for the remaining units as well. Thus, postponement of conveyancing or formation of the condominium organization until plans have been completed for all units or until all have been constructed may not result in unbearable delay. Even here, however, these requirements can be irksome, since a purchaser will be unable to acquire his unit until the builder has sold the remaining units or has drawn up final plans for them in accordance with the purchaser's desires concerning layouts, dimensions, and other vital

38 See, e.g., Fla. Stat. Ann. $\$ 711.09$ (1) (e) (Supp. 1969); N.Y. Real Prop. LAW. \$339-p (McKinney 1968); cf. WASH. REV. CoDE ANN. \$64.32.100 (1966). But see, e.g., Cal. Bus. \& Prof. Code $\$ 11535.1$ (Supp. 1968); Col. Rev. Stat. ANN. §118-15-5(1) (1963).

39 FHA Moder ACT $\$ 13$ (1962) provides for both the filing of floor plans and a verified statement of a registered architect or licensed professional engineer certifying that the plans are accurate copies of those filed and "approved" by the proper municipal authorities. In addition, before the first conveyance of any apartment, a verified statement must be filed that the plans accurately depict the layout, location, apartment numbers and dimensions of the apartments "as built" thus preventing conveyance of even one until all are completed. Id. \$13. See, e.g., CaL. CIv. CodE § 1351 (West Supp. 1968); Ded. Code AnN. tit. 25, \$2220 (Supp. 1968) ; HawaII Rev. Stat. tit. 28, \& 514-13 (1969); ILI. ANN. STAT. ch. 30, \$ 305 (Smith-Hurd 1969); P.R. LAwS ANN. tit. 25, $\$ 2220$ (Supp. 1966). See also Ferrer, Sone Practical Aspects of Condominium Lave, 2 Proceedings ABA Real Property, Probate, and Trust Section 27,32 (1965).

40 See N.Y. Real Prop. Law \$339-p (McKinney 1968) ; WIs. Stat. AnN. \$230.82 (Supp. 1969). 
matters. These statutory restrictions can be even more onerous if there is to be more than one multi-unit building in the development.

In a lateral subdivision consisting of detached one-family houses, these statutory requirements are completely inapposite. A developer simply cannot prepare final plans in advance for all units where they will depend largely on each individual purchaser's desires and specifications. The design and size of future units are not limited by those already sold and they may even differ radically. In fact, the developer may not even have decided upon the number of units to be included in the development, preferring to postpone this decision until he is able to measure the market reaction to his homes.

Condominium legislation may thus impose upon developers tremendous handicaps and delays which hamper sales. Meanwhile, competitors down the street, offering homes in conventional subdivisions, may convey any home without waiting until they have planned, constructed, or sold all of the other homes in the development. ${ }^{41}$ Even where purchasers are willing to enter into purchase contracts in the face of such delays, the developer may suffer irreparable loss by having his investments frozen while his costs mount, until he is able to construct and sell all of the planned units.

A system of drafting tentative plans, recording them when the condominium organization is put into operation, and altering them for individual purchasers is attractive but not feasible. The initial plans required to be filed may need approval by local governmental building authorities $^{42}$ at substantial additional cost. Such change of plans can be effected only by a condominium charter amendment, which commonly requires the consent of a majority of the owners ${ }^{43}$ unless the developer retains sufficient voting power to amend without the consent of prior purchasers. Such advance consents may not be legally binding, since they may not fulfill the disclosure requirements of state blue sky laws, and may be held to result in the practical circumvention and nullification of the consent requirements of the statute. Such a situation may impose a serious handicap on the developer, who would

41 In a number of states, the filing of plans, construction of some of the facilities, or the posting of performance bonds assuring their completion, may be required by subdivision laws. E.g., HawaIr Rev. Stat. tit. 6, \$65-23 (1969); Kan. Stat. AnN. $\$ 1275$ (b) (Supp. 1968); OHIo REV. CODE ANN. \$711.101 (Page Supp. 1968); Mo. ANN. STAT. $\$ \$ 64.060,64.580$ (1966); N.Y. Town LAW $\$ \$ 244 a-1,265-a, 276-78$ (McKinney 1965); W. VA. CODE ANN. \$\$ 8-5-28 to 8-5-30 (1966). However, these construction and bonding requirements refer to such items as sewers, streets, and utility connections but not to the housing structures themselves.

42 E.g., Alaska Stat. $\$ 34.07 .030$ (Supp. 1968); Conn. Gen. Stat. Ann. \$47-71(c) (Supp. 1969); N.Y. REAL PROP. LAW \$339-p (McKinney 1968).

43 See Alaska Stat. \$34.07.020 (13) (Supp. 1968); N.Y. Real Prop. Law \$339-v(1) (j) (McKinney 1968); WAst. Rev. CodE ANN. \$ 64.32.090(13) (1966). Sixty per cent of the owners can approve amendments in Washington and Alaska, and, presumably, $662 / 3 \%$ in New York. 
have to obtain new consents as each additional unit was sold and its plans changed at the purchaser's request.

The difficulties in this area are compounded by ambiguous statutory phraseology. Under the statute originally enacted in New York, a developer was permitted to sell units which had not been constructed, provided that he completed the units before conveyance and recorded a verified certification that the plans filed for the units "fully and fairly depict the layout, location, unit designation, and approximate dimensions of the units as built." 44

The statute was thereafter amended, since the fact that it required a certification for the "units" (in the plural) raised a

doubt as to whether all of the units of a town house or garden apartment condominium cluster had to be completed before any unit could be conveyed. While . . . the new language [may be considered] declarative of the original statute, the additional emphasis by the new language should be helpful. It would have been most unfortunate if the developer of a 200 unit town house condominium would not be permitted to convey a single structure until all 200 units have been completed. The law is now clear and accords with the practicalities of home building. ${ }^{45}$

The statute, as amended, now permits the conveyance of any unit upon a verification that the plans "fully and fairly depict the layout, the location, unit designation, and approximate dimensions of any particular unit or units as built," rather than requiring that the verification encompass all units in the development. ${ }^{46}$

Where the developer utilizes the home owners association, he may be relieved of the necessity to complete the homes or even to file detailed building plans that have been approved by the local building code authorities. Even localities which require the filing of detailed specifications or assurances that the facilities will be completed, frequently limit these demands to public improvements such as streets, sewers, and utility connections, and do not include the residential structures, or

4 Act of March 2, 1964, ch. 82 \$339-p, 1 Laws of N.Y. 96, 102 (1964), as anended N.Y. REAL Prop. LAW \$339-p (McKinney 1968) (emphasis added).

45 D. Clurman, 1965 Amendments to the New York Condominium Act, New York State Department of Law 2-3 (1965).

46 N.Y. Real Prop. LAw \$339-p (McKinney 1968) (emphasis added). In Hawaii, where the statutory language is identical with the New York wording (except that the term "apartments" was used in the Hawaiian statute instead of "units"), Act of May 29, 1963, $\$ 13$, [1963] Sess. Laws of Hawaii 102 (amended 1964), this was interpreted as requiring only the completion of the individual apartment to be conveyed. See Act of April 15, 1964, [1964] Sess. Laws of Hawaii 8, which stated that the aforementioned provision "prevents the conveyance or lease of any condominium apartment until the completion of the construction of the condominium apartment." It should be noted that "apartment" is used in the singular. 
permit the plans to be amended easily in these respects without the consent of prior purchasers. The home owners association may therefore offer distinct advantages for the developer.

\section{The Common Facilities}

The provisions of condominium legislation that require construction plans to be filed, or units to be completed before any unit is conveyed were designed to protect the purchaser of a home and to assure completion of the development. These statutes do not commonly require proof that the common facilities, as well as the units, have been built. ${ }^{47}$ This omission may have resulted because the legislators envisaged high-rise structures, where erection of the units would presumably also entail the construction of common elements located in the same building. Even here, however, the common facilities may not always be located in the same structure as the dwelling units; a swimming pool, or a parking lot, for example, may be located outside the apartment house. Statutes should therefore provide the same assurance and protection to purchasers regarding the common areas that they do for the units themselves. While the filing of plans and assurances of completion of common areas for lateral units may be covered by the subdivision statutes and regulations, these tend to be less onerous than provisions of the condominium laws, and may not afford the needed protection to the purchaser.

\section{B. Apportioning the Common Interest Among Unit Ozeners: The Problem of the Unknozen Common Interest}

The condominium statutes require that each unit shall receive a specified allocation of an appurtenant undivided interest in the common elements, ${ }^{48}$ commonly based upon the value or sizes of the units. This interest frequently determines the share of common expenses each unit owner shall pay, the number of votes he may cast, and his share of any

47 See, e.g., N.Y. Real Prop. LAW $\$ 339-\mathrm{p}$ (McKinney 1968) which provides "there shall be filed ... a set of the floor plans . . showing the layout, locations and approximate dimensions of the units ... See also statutes cited note 39 supra.

48 See Hawam Rev. Stat. tit. 28, §514-6(a) (1969); Ill. Ann. Stat. ch. 30 $\$ 304$ (c) (Smith-Hurd 1969); N.Y. REAL PROP. LAW \$\$339-1(i)-(ii) (McKinney 1968) (permits the size of a unit to be used as a determination of its common interest) ; WASE. REv. CODE ANN. \$§ 64.32.050(1), 64.32.090(6) (1966).

The California statute, CAL. CIv. CoDE \&1353(b) (West Supp. 1968), provides that the interests of all units shall be equal unless otherwise provided in the declaration. This would appear to be unfair to the purchaser of a more expensive unit who would receive only the same amount of distributions as the owner of a lower price unit in the event of a distribution of condemnation award, proceeds of insurance paid as a result of the destruction of the condominium project, or the partition and sale of all units upon the termination of the condominium. See also Mrss. Code ANN. 8 896-07 (b) (Supp. 1968). 
proceeds upon condemnation, destruction, or sale of the entire development. ${ }^{49}$

Here too, the high-rise oriented condominium legislation contemplated a situation where all common interests could be apportioned at one time, since all units would be located in one structure and would consequently be completed together. While variations in value or size of units may make apportionment unwieldly even for apartment house condominiums-especially multi-structure developments-the allocation of interests will commonly be extremely difficult, if not impossible, in a lateral development prior to its completion. The developer may not know the sizes, features, and, consequently, the prices of the unsold units to be built to specification; sometimes he may not even know the number of units which will ultimately be erected in the project, and may defer his decision until he can gauge the success of his sales program. The present statutory scheme will prevent him from conveying any unit until he has obtained purchasers for all of the units planned for the subdivision.

The problem is compounded in those states which require that the value of the units at the date of the declaration, rather than the date of sale, be used as the criterion for establishing the common interests. ${ }^{50}$ At that date, many units may not be built. They consequently have no value at that time, except for the value of the lots upon which they are to be erected and the land which is to be owned in common by all unit owners. Given the indeterminables of value, size, and number of units in the development, common interests cannot be allocated to any unit until the very last unit is sold, as long as the interest of each unit is made dependent by statute on the ratio of its value (or size) to the aggregate value (or size) of all units.

\section{Altering the Common Interest}

If a developer sells some of the units and wishes the condominium organization to commence operations, he must record the charter containing allocation of common interests to all units, including those that have not yet been sold. Since the allocation of interests is generally fixed and is not subject to change unless the unit owners in the development consent, ${ }^{51}$ the developer may be bound unreasonably. Fluctua-

40 In some states value or size is not prescribed as the basis for determining the common interests. See, e.g., CAL. CIV. CoDE $\$ 1353$ (b) (West Supp. 1968); FIA. Stat. ANN. $\$ 711.08$ (1969); PA. Stat. ANN. tit. 68, $\$ 700.202$ (1965); VA. CoDE ANN. \$55-79.6 (1969); WIs. Stat. ANN. \$230.75 (Supp. 1969).

50 N.J. Stat. Ann. \$46:8A-6 (Supp. 1968); N.Y. Real Prop. Law §339-j (McKinney 1968).

51 Some statutes require the consent of all unit owners for a change in the common interest of any units. E.g., ILL. ANN. STAT. ch. 30 \&304(c) (Smith-Hurd 1969); P.R. LAws ANN. tit. 31, §1291(f) (1968); WASH. REv. CODE ANN. \$ 64.32.090(13) 
tions in the market demand for units may result in the sale of units with identical common interests for substantially different prices. Will the price variations be considered as proof that the common interests were not apportioned according to the value of the units as required by the statutes? In addition to the problem of establishing interests where the developer does not know the number and prices of units to be built, complications are likely in lateral complexes constructed in sections. A longer time may elapse between the sale of the first and last units, with greater possibilities of price variations.

Although variations in price are not likely to prevent the applicability of the condominium statutes, particularly in states where the value at the date of the declaration is the criteria to be used ${ }^{52}$ in establishing the interests, this basis may be unfair to the purchaser of the unit who pays more for it than the value originally set at the prior declaration date. It may be argued, however, that this is no different than the purchase of corporate securities in a rising market at a price higher than that which previously prevailed. There is no reason why any unfairness resulting from price fluctuations should be less tolerable in condominiums.

From the purchaser's perspective, the problem becomes particularly acute when he subsequently increases the unit's value vis-a-vis the other units by extensive improvements. Should not his common interest be increased so that he will be entitled to a larger share of the proceeds of sale or condemnation (or insurance proceeds in the event of destruction) than his neighbor who has invested less money in the unit? The possibility of such change in the relative value of units is greater in lateral developments than in high-rise, because the larger physical separation of the units may make it advisable for the by-laws to permit individual owners to improve and enlarge their units to a much greater extent than is the case in high-rise condominiums. ${ }^{53}$ Similarly, because of the physical independence of the units, each individual owner may be required to maintain his own unit and those portions of the common elements reserved for his exclusive use, rather than have such main-

(1966). Others permit a change with the consent of the unit owners affected thereby. E.g., N.Y. REAL PROP. LAW \$ 339-i(2) (McKinney 1968); ORE. REv. Stat. \& 91.610(1) (1965) ; PA. Stat. tit. $68 \$ 700.202$ (1965). It would appear, however, that all unit owners would always be affected by a change in the common interest of any unit unless a compensating change was made for another unit.

The California statute, while it does not specifically provide for amending the common interests, provides for amending the declaration of restrictions (which may set forth the percentage of interest in the common elements), even if this increases the burdens upon the units; such a change in common interests apparentliy may be made by the holders of a majority of the common interest even where the particular owner affected objects. CAL. Crv. CoDE $\S 1355$ (c) (West Supp. 1968).

52 Note 50 sipra.

53 See N.M. Stat. ANN. \$70-4-8 (Supp. 1967) ; N.Y. Reat. Prop. LaW \$339-k (McKinney 1968); P.R. LAws ANN. tit. 31, \$1291(m) (Supp. 1966). 
tenance be undertaken and paid for by the condominium organization. Different degrees of maintenance and, therefore, of value may result.

The provisions of the Alaska and Washington statutes, ${ }^{54}$ calling for periodic reappraisals of the units and common elements with concomitant reapportionment of common interests, may be equitable, but may also cause difficulties. Although periodic reappraisals are common for casualty insurance purposes, changing unstable common interests can affect the mortgageability of the units and result in constant realty tax reassessments based upon the revised common interests.

The solution may lie in amending the statutes to require that the proceeds of condemnation, destruction of the units, or termination of the condominium organization, be distributed in accordance with the value of units at the time of such event (rather than in accordance with the common interests), or that a separate condemnation award be made for each unit. The appraisals that would be required are basically the same as those made when a home in a conventional development is destroyed or condemned. Where one blanket casualty insurance policy covers all units, periodic reappraisals may be necessary to ascertain the value and coverage required for each unit.

Alternatively, it may be feasible for each unit to maintain a separate policy of casualty insurance. The proceeds receivable by any owner would then depend solely on the value of his own unit, and not upon the ratio of the common interest or value of his home to those of his neighbors. Whereas separate policies may not be advisable for a highrise building in which physical intermingling of the units and common elements makes it difficult to allocate damages and insurance proceeds, ${ }^{55}$ they may be practical for lateral developments where each unit is completely separated physically from the other units and destructible common elements.

\section{Planning the Common Interests Under Present Statutes}

In the face of the present statutory requirements that the interests be fixed for all units before title to any is conveyed, and the difficulties in altering these interests once established, the developer has a number of choices. He can surrender his flexibility and bow to the dictates of the statute by definitely fixing in advance the number and prices of units. Or he can retain some room for maneuvering by allowing purchasers the option of minor variations in the unit specifications, while disregarding such variations in allocating common interests. Where

54 Alaska Stat. $\$ \$ 34.07 .050,34.05 .180$ (b) (Supp. 1968).

55 See Rohan, Dismution of the Condominium Venture: The Problems of Casualty Loss and Insurance, 64 CoLUM. L. REv. 1045 (1964). 
the prices are only slightly varied when the purchaser exercises such options, it is likely that this arrangement will satisfy the statutory requirements for allocating common interests in proportion to value. ${ }^{56}$ This approach greatly restricts the developer's overall flexibility in offering important options and prevents him from increasing the size of the development if market reaction is favorable, thereby reducing the overall fixed costs of the project allocable to each unit and maximizing his profits.

If the developer nevertheless wishes to retain his freedom of choice of the ultimate number of units to be contained in the development and also wishes to offer a wide variety of options, there are three general approaches he can take.

\section{Delaying Fixing the Common Interests}

The developer may begin to sell units but postpone conveying title to any unit and recording the condominium charter, thereby delaying legal formation of the condominitum project and determination of common interests. Each contract for the sale of units would be conditioned on the sale of a specified minimum number of units (calculated to be sufficient to make the development viable) by a named date and would obligate the developer to decide at that time the precise number of units (up to a stated maximum) to be included in the project. Common interests could be apportioned pursuant to the formula detailed in the contracts of sale. ${ }^{57}$ If he does not sell the specified minimum number of units by the given date, the contracts would be terminated and the deposits refunded.

While this approach may overcome the statutory rigidity regarding fixing and altering common interests, it does not provide the developer with a great deal of flexibility to postpone decisions regarding the number of units to be constructed. He is also obliged to greatly increase his normal risks by deciding in advance on just the right combination of the number of units to be sold and the length of the trial period in which to sell them. If he establishes too large a quota or too

56 See, e.g., N.Y. REAL Prop. LAW \$339-i(1) (McKinney 1968), which states: "Such interest shall be (i) in the approximate proportion that the fair value of the unit of the date of the declaration bears to the then aggregate value of all the units or (ii) in the approximate proportion that the floor area of the unit at the date of the declaration bears to the then aggregate floor area of all the units...." (emphasis added).

57 See Offering Plan of Westchester Hills in Greenburgh, New York (1965) which specified that the project would contain between 101 and 215 units, with the exact number of units and the apportionment of common interests to be determined by a specified date prior to the recording of the declaration and the conveyance of title to any units. 
small a time period, or if his judgment is good, but his luck bad, and he is unable to meet the deadline, he must abandon the development and may lose his investment. Even if his judgment and luck are both good, once he records the charter, he cannot add any units to the development without consent of the owners.

A further disadvantage of this approach is that purchasers may be unwilling to contract to buy a home if they do not know in advance the precise number of units to be included in the project, and if they are unaware of their respective common interests and their share of common expenses. This may be particularly true where there are to be extensive common facilities which must be maintained by purchasers of the units, regardless of the number of homes which may ultimately be included in the project. Consequently, the individual purchaser's common charges may be exorbitant if there are only a few units in the development.58 On the other hand, some purchasers may fear that the development will be too large and crowded for their tastes. Others may be unwilling to wait until the deadline to find out if their purchase will become a reality or to postpone closing title to their units until the cut-off date, particularly if they have to make other advance commitments-selections of schools for their children, for example. If these disadvantages are added to the possibility that the condominium project may never be formed because of insufficient sales, the prospective purchaser may well prefer to purchase a home in a conventional development. ${ }^{59}$ If a developer attempts to shorten the period of uncertainty and reduce the number of units which must be sold in that time, his profit may be seriously affected.

A builder may attempt to overcome these risks by providing that the sales contracts are not to be terminated even if he fails to sell the requisite number of units by the cut-off date, as long as they are to be constructed by him. Even if purchasers would agree to this arrangement, it may result in a drastic reduction of the developer's profits. If his sales contracts or the applicable local law require him to construct the additional units in advance of their sale, he may tie up a substantial investment if he is unable to sell them for some time. If not required to

58 This difference may be overcome somewhat by tailoring the extent of common facilities to the number of units which may be sold, and by providing for basic minimum common facilities which would be expanded as additional units are sold. Of course, these facilities must be sufficient to satisfy the requirements of purchasers both as to the extent of the facilities offered and the burdens entailed in their demands. Such arrangements tend to be unduly complicated.

59 Remarkably enough, although all of these uncertainties existed in the Westchester Hills Condominium, see note 62 supra, all of the units were rapidly sold, indicating perhaps that reasonably priced attractive units are very saleable, particularly where the development offers recreational facilities not available in competing conventional developments. 
construct these units, he will still have the continuing financial obligation to pay common charges and other expenses on such units. ${ }^{60} \mathrm{He}$ will also be involved in the complicated determination of just which expenses he must bear for units that are as yet unbuilt, ${ }^{61}$ and whether his exemption from any of the expenses complies with the statutory requirements that normally all common expenses are to be shared by all of the unit owners.

The purchaser may also be adversely affected by the sponsor's retention of management control or, at the least, considerable voice in management through ownership of unsold units. Where the units are constructed, the developer may be forced to lease these units to offset his financial burdens, with the result that a considerable number of units may be occupied by persons who are not owners and whose interests differ from those of unit owners.

The developer who uses this approach to delay fixing the number of units to be contained in the project may also find that mortgage lenders are unwilling to commit themselves to provide mortgage loans for the units. ${ }^{62}$ Finally, in states where blue sky laws are applicable to public offerings of condominium units, the developer may have diffculty convincing the enforcement authorities about the feasibility of such arrangements or about the adequacy of disclosure to purchasers of the potential results of the sponsor's inability to sell the requisite number of units. ${ }^{63}$ At best, under this approach the developer would still be forced to delay conveyances until the cut-off date and would be inflexibly bound by the number of units that he was obliged to establish for the development.

60 See, e.g., N.Y. REAL Prop. LAW §339-m (McKinney 1968) which states: "[T] he common expenses shall be charged to, the unit owners according to their respective common interest . . ."; D.C. CodE ANN. \$ 5-916(a) (1967). See also Alaska Stat. \$34.07.140 (Supp. 1968); MD. Ann. Code art. 21, §131 (1966). See generally Ferrer, Some Practical Aspects of Condominin Law, 2 Proceedings ABA Real Property, Probate, and Trust Section 27, 33 (1965).

61 Expenses such as insurance, maintenance, or personnel are commonly incurred only for units which have already been constructed. A developer may, therefore, be justified in attempting to relieve unbuilt units of the obligation to contribute towards these expenditures.

62 See remarks of William B. Anzelone in Long Island Home Builder, 1965, that the number and features of all units must be fixed before a lender will make such a loan.

63 Such offerings have been permitted in New York State. Note 57 supra. In New York State, however, a developer who has not yet constructed units may obviate somewhat the problem of the unknown common interest by receiving permission to solicit indications of interest under the procedure set forth by the New York State Attorney General pursuant to its "Cooperative Policy Statement No. 1." After thus fathoming the desires of potential home purchasers, he can decide how many units to include and what types of houses to build. Such advance consent may be technically unnecessary in view of the authorization of N.Y. GEN. BUS. LAw \&352-e(1) (a) (McKinney 1968) to solicit indications of interest, prior to registration. 


\section{Tentative Fixing of Common Interests}

Where the developer desires to be able to increase or decrease the number of units in the development without delaying the closing of title, he may consider a slightly different approach. He can sell homes, establish the condominium organization, tentatively fixing common interests for the units planned, and, at the same time, obtain an authorization from every purchaser to change the common interests of the units at a specified future date. Such alteration would be made in accordance with a stated formula which would be based upon the ultimate number and prices (or sizes) of the units at that time. This is similar to the first approach outlined above, except that here units can be conveyed and the condominium organization can commence its operations before the cut-off date is reached. Such alteration of common interests is provided for in the Alaskan and Washington statutes. As an alternative or supplement to this approach, a builder may obtain the right to reallocate the common interests by appropriate provisions in the legal instruments establishing the condominium projects. ${ }^{84}$

While this procedure may be permissible in states that have no provision requiring the fixing of common interests, ${ }^{65}$ it does not comply with the statutes of the majority of states which require fixing common interests for each unit upon the formation of the condominium project, assuming this requirement implies the establishment of a specified interest rather than a formula governing subsequent determination of the common interests at some future date. It is also doubtful whether this approach would meet disclosure requirements of states which have blue sky regulations for condominium developments.

Another major drawback of this approach is the probable unwillingness of lending institutions to finance construction of the project or the purchase of any unit when the number of units and the common interests appurtenant to units are uncertain. This indefiniteness may raise problems regarding the soundness of the mortgage investment, as well as legal objections to investing in units with common interests of undetermined extent and value. ${ }^{60}$ Purchasers, too, may be unwilling to commit themselves for the same reason.

Many of the other disadvantages of the first approach outlined above apply here as well. The developer's flexibility terminates at the

64 Alaska Stat. $\$ 34.07 .180$ (Supp. 1968) ; Wash. Rev. Code ANN. $\$ 64.32 .060$ (1966). The Alaska statute, however, may prohibit the conveyance of any units until all are constructed. AlASKA Stat. \& 34.07 .040 (Supp. 1968).

65 See Cal. Crv. Code $\$ 1353$ (West Supp. 1968) ; Col. Rev. Stat. Ann. \$118-15-2 (1963) ; Mrss. Cone ANn. \$ 896.07 (Supp. 1968) ; Nev. Rev. Stat. \$117.040 (1963).

68 Note 62 supra. But see note 57 supra for condominium projects where the lending institutions involved did issue mortgage commitments before final determinations were made of the precise common interests for all units. 
cut-off date, which, as a practical matter, often cannot be deferred very far. Problems will arise regarding the charges that the developer should pay for unsold units which he may later construct, and the votes which he may cast for such units. These problems can be ameliorated only by limiting possible variations in the size of the subdivision and by narrowing the time in which charges can be effected, thereby restricting the developer's flexibility.

\section{Staged Developments}

In order to avoid the limitations of a cut-off date, the developer can utilize a third approach and build the project in separate stages. The first stage could constitute a separate condominium entity, consisting of a relatively small number of units. The number selected would have to be small enough to sell readily, yet large enough to make the project viable and to prevent unduly large assessments in support of the common facilities. ${ }^{67}$ The developer could tailor the extent of common facilities to the number of units. The first stage might contain only minor recreational facilities, such as open space and some tennis courts, leaving the expensive recreational developments for future stages. As another section (which might remain a distinct entity) is added, a recreation building might be included in it. When the third section is added, a swimming pool could be integrated into the recreation com-. plex. ${ }^{68}$ The developer would not, therefore, be troubled by uncertainties concerning the number of units that he should ultimately include in the entire development. As he decides to sell more units, he could simply add additional sections.

If the developer wants to give purchasers in each section an option to choose the type of units they desire, the staged development method can be combined with the first approach above by contracting for the sale of units before allocating common interests and postponing the date of title closing for units in the section until all are sold. Because of the small number of units included in each stage, the cut-off date can be set in the near future, thus reducing the period of uncertainty as well as limiting the quantity of homes involved at any one time in the aforementioned problems.

The staged development approach has added advantages for the developer. First of all, he minimizes his capital risk by investing only in a small number of unsold units. At the same time he still retains his flexibility in determining the ultimate number of units to be added to the complex. Equally important, the developer can utilize the

67 See Bulletin, supra note 2 , at 20 , which suggests that 50 units may be the minimal desirable number.

68 Id. 21. 
experience he gains in selling units in the first section and in studying its operations, to modify his plans regarding subsequent sections. Thus, he may wish to either increase or decrease prices in accordance with his sales experience in the first section. By organizing each section as a separate condominium development, these price changes for the subsequent sections are not subject to attack on the grounds that the common interests were disproportionate to value, contrary to the provisions of the condominium statutes. Sales in the earlier sections may also assist the developer in adding or deleting features in the units and common facilities, or in amending the by-laws or modus operandi of the subsequent sections.

Another advantage of staged development is that filing plats for the entire tract may result in increased tax assessments for the entire acreage, although the condominium documents are not recorded and there is no assurance that all of it will be developed. Similarly, the areas projected on the plat for common use may be deemed irrevocably dedicated for this purpose, or be interpreted as easements for purchasers in any portion of the tract. If adverse sales experience causes the developer to abandon construction of homes for the entire tract, he may not be able to recover these common areas. ${ }^{69}$ By use of staged developments, only one small common area at a time will be set aside. The developer may also avoid the necessity of completing facilities on the whole tract before approval of subdivision of any portion thereof, ${ }^{\mathbf{7 0}}$ since these prescriptions may not apply to unplotted areas.

Even though he may not choose to do so, the developer may be forced to construct in stages if he is unable to obtain mortgage commitments for all of the units ultimately planned for the entire development. Mortgage lenders might wish to study the market reaction to unit offerings as well as the operation of the first project section.

\section{E. Integrating the Development Sections}

Unless the sections are to operate independently of one another, there are two basic problems which must be resolved: how to handle those areas in any one section that are to be used by the owners of units in all sections (referred to hereinafter as Overall Common Areas), and what shall be the legal relationship of the different sections to each other? If the developer desires to merge all of the sections into one

69 See Ryerson v. City of Chicago, 247 III. 185, 93 N.E. 162 (1910). See also HANDBOoK, supra note 2, at 304; Rohan, Second Generation Condomininm Problems: Construction of Enabling Legislation and Project Documents, 1 Valpararso L. REv. 77, 87-89 (1966); J. KrazNowiecki, Legar Aspects of Planned Unit Residentiai Development 50 (Urban Land Institute Tech. Bull. 52, 1965).

70 Urban Land Institute, Legal Aspects of Planned Unit Residentiai Development 51 (Urban Land Institute Tech. Bull. 52, 1965). 
condominium organization, the Overall Common Areas would be absorbed by the common area of the enlarged condominium entity. Unless the "tentative fixing" approach is also used, and advance consents are obtained or authorization is provided in the respective charters, such merger may not be feasible due to the problem of changing common interests.

Short of merger, the developer has a choice of an almost infinite variety of relationships ranging from complete independence of the sections to forming a federation. For example, he can arrange for the portion of Overall Common Areas located in each section to constitute part of the common area of that section only, which would maintain it solely at its own expense. This arrangement would be coupled with cross-easements providing the unit owners in other sections with the irrevocable right to use these common elements. The foregoing solution is feasible where the Overall Common Areas are evenly distributed throughout all sections so that all owners would share the maintenance burdens equitably.

A more desirable alternative may be a two-tiered system. Although the portion of the Overall Common Areas located in any one section remains the common area of that section with title vested exclusively in its unit owners, a separate entity, either a non-profit association or corporation (hereinafter called Overall Entity), would be superimposed upon the separate condominium organizations to manage the Overall Common Areas. Provision must be made for representation on this entity by the owners of units or the board of managers of each section, with the vote allocated equitably-perhaps, in accordance with the number of units in each section. Ideally, monetary assessments required by the Overall Entity would be allocated ratably among the smaller entities, which in turn would include this amount in their respective common expenses, bringing to bear the powers granted by the condominium statutes for the enforcement of such payment by unit owners. Decisions of the Overall Entity concerning policies, improvements, and other matters should similarly be approved by the board of managers of each section to insure their enforceability. ${ }^{71}$

However, a two-tiered system may present some difficulties. Assuring access to and use by all unit owners of the Overall Common

71 The developer of Hillcrest Park, a condominium project in Peekskill, New York, formed separate condominium organizations for 4 successive sections, and utilized a corporation to maintain facilities common to all 4 sections. See Offering Plan for Hillcrest Park Condominium, 1966.

Multi-tiered levels of organizations have been successfully used in non-condominium projects, such as J. C. Nichols Country Club, Kansas City, consisting of approximately 29 separate associations, and Roland Park, Baltimore, Maryland. Similar arrangements have been provided for Reston, Virginia, which is ultimately to be divided into seven component portions, with multi-tiered organizations. 
Areas is a problem, since each portion will constitute the common elements of an individual section. Recordation of cross-easements of use in favor of all owners raises the serious legal question whether future purchasers who were not parties to the original agreements are bound. Unlike negative covenants prohibiting specified acts, there is doubt in some states as to the enforceability of affirmative covenants or equitable charges. $^{72}$

Assuring access to the common facilities by recording covenants and easements may be unwieldy under certain circumstances. Where there has been no firm decision by the developer concerning the nature and extent of future communal facilities to be constructed in other sections, or concerning the number of additional units to be constructed, the compulsory future integration of additional sections may take place under completely new and unanticipated circumstances.

Enforcing decisions of the Overall Entity is a related problem; easements and covenants may not be sufficient. Even though condominium laws make these decisions binding on each section when adopted by the local board of managers, the rejection by any one board of managers frustrates the implementation of decisions which require uniform conduct by the unit owners in order to be effective.

Decisions made by a board of managers of a condominium development are enforceable pursuant to the various state condominium statutes, but they may be inapplicable to the decisions of the Overall Entity. There is even the possibility that individual condominium sections may be deemed to be outside the framework and protection of the condominium statutes, since they would be subordinated and subject to the decisions of the Overall Entity. However, title policies insuring against such risks ${ }^{73}$ may afford some protection.

It is possible that assessments and compliance with decisions of the Overall Entity may be enforced by incorporating these requirements as part of a second mortgage on each unit in favor of the Overall Entity. To assure validity of the mortgage it would be advisable to provide for an existing mortgage debt in a specific amount. This is easily arranged by having the Overall Entity lend an amount of money equal to one year's estimated assessments to each unit owner. This sum would be the face amount of the mortgage. Proceeds of the loan, plus additional amounts contributed by the unit owner, could be set aside in an escrow amount to assure the payment of future assessments. There is no reason why these provisions should not be enforceable against

72 Text accompanying noles 123-32 infra.

73 Title policies insuring that the arrangements complied with the condominium legislation were issued for the condominiums at Hillcrest Park, New York. See note 71 supra. 
subsequent purchasers as a lien upon the unit in the same way as any other mortgage provisions requiring affirmative acts-payment of realty taxes and insurance premiums, for example. ${ }^{74}$ Personal liability of subsequent purchasers can be assumed by providing in the mortgage instrument that the mortgage debt becomes due when the mortgagor sells his unit, unless the vendee personally assumes the mortgage. Similar provisions are common in mortgages and are not regarded as unreasonable restrictions upon alienation, ${ }^{75}$ nor are they found unduly objectionable by unit purchasers. Even in jurisdictions that hold these provisions to be a restraint, they may be valid if the condominium statutes permit restrictions on alienation ${ }^{76}$ which are necessary for the viability of the development. ${ }^{77}$

Where the boundaries of the Overall Common Areas are set in advance, it may be feasible to include an undivided portion of the Overall Common Areas in the common elements of each separate condominium section. In this way, each portion of the Overall Common Areas constitutes part of the common elements of each section. Nevertheless, the problem whether an area may constitute the common elements of more than one condominium organization, and the related difficulty of apportioning interests equitably among the various sections, would remain.

It may be more desirable and simpler, therefore, to arrange for a horizontally diffused structure of organizations in which the Overall Common Areas could be owned and managed by a separate entity. The purchaser of a unit in any section would automatically receive membership in this organization and participate in the condominium organization controlling his section. ${ }^{78}$ This arrangement combines the condominium and tract association formats. Each section manages its own affairs as in the ordinary condominium, while the Overall Common Areas are owned and managed exclusively by the separate entity. In this way, it is possible to avoid some of the duplication of the vertically-integrated system, where each decision of the separate entity must be approved and repassed at a lower level by the board of managers of each condominium entity. Since condominium legislation

74 See G. Osborne, HandBook on the LAw of Mortgages 695 (1951).

75 For a general discussion of acceleration, see $i d .950-51$.

76 See, e.g., N.Y. ReAL Prop. LAw $\S 339$ (v) (2) (a) (McKinney 1968) (permitting nondiscriminating restraints on alienation).

77 See Berger, Condominizm: Shelter on a Stantory Fonndation, 63 CoLUM. L. REv. 987, 1018 (1963).

78 Such form or organization was provided for in Leisure Village, a condominium project in Lakewood, New Jersey, consisting of several different sections. The owner of a unit in any section has a voice in the corporation owning the recreational facilities used by owners of units in all sections. See Offering Plan of Leisure Village, Lakewood, New Jersey (1966). 
would probably not apply to assure enforcement of the decisions of the Overall Entity, they would have to be enforced like those of home owners associations. Assessment decisions made by the separate entity may also have to be duplicated and levied as common charges by the board of managers of each condominium section in order to provide a stronger assurance of their enforceability. Use of a separate entity to own the Overall Common Areas requires a separate mortgage, which must be expanded both in amount and scope as additions are made. However, separate mortgage loans might be obtained for the additions. The complexity of establishing and altering common interests and expanding the development is greatly reduced when a home owners association is used. This format has in the past ${ }^{79}$ allowed the developer great flexibility in providing for additions to the development and for the consequent changes in voting rights and allocation of common expenses. There is no problem if the value of any home increases disproportionately; the home owner reaps the benefit of such appreciation upon its sale, destruction, or condemnation exclusively, unaffected by his interest in the home owners association, which only concerns his rights and obligations in the common facilities. The home owners association format thus has distinct advantages for the developer over the condominium structure.

\section{F. Unsold Units: Allocation of Expenses and Votes}

Paralleling the problems of establishing interests for units to be sold pursuant to the condominium statutes are problems of allocating the common expenses and voting rights between the developer and unit purchasers. It is important to determine whether the developer is to be responsible for the payment of common charges for unsold units and, if so, whether his liability covers all common charges or only those which are incurred for units already constructed and occupied. If the developer does not wish to pay a portion of insurance, personnel, repair, maintenance, or electrical expenses, which are not incurred for unsold units to the same extent as for those that are occupied, he must

79 See HANDBOOK, supra note 2 , at 346-50. Unless provisions are initially made for the admission of the purchasers of units to be constructed in the future, even nonprofit corporations may be bound by the rights of the earlier members or stockholders against dilution and their right to an appraisal resulting from a change in the control of the corporation because of the construction and sales of additional units. See 1 G. HoRNSTEIn, CoRporation LAW AND PRACTICE $\$ 362$ (1959); 2 id. $\$ \$ 623-26$, 629; Lattin, Minority and Dissenting Shareholders' Rights in Fundamental Changes, 23 LAW \& CoNTEMP. PRoB. 307 (1958); Lattin, A Primer on Fundamental Corporate Changes, 1 W. Res. L. REv. 3 (1949). See also Troupiansky v. Henry Disston \& Sons, Inc., 151 F. Supp. 609, 611 (E.D. Pa. 1957).

The use of a nonprofit corporation has been reported to be common in England due to the legal difficulties present there of owning undivided interests in common elements. Leyser, The Ozmership of Flats-A Comparative Study, 7 INT'L \& CoMp. L. Q. 31, 51-52 (1958). 
obtain advance consents of purchasers for this arrangement and should provide for it in the condominium charter. In addition, he must ascertain whether the applicable condominium statutes permit the owner of any unit to be absolved from the payment of his share of common expenses allocated according to common interests. ${ }^{80}$ If the unit purchasers waive these payments by the developer and assume common charges that would otherwise be allocable to unsold units (either in the interest of fairness or because each owner's extra burden becomes small when spread among all purchasers) the problem may not exist.

Determining the developer's share of common expenses is more difficult if the developer does not know the number of additional units he may construct or the types and prices of homes that he may build. Nevertheless, it is only fair that he should agree to pay for a portion of the common expenses to insure that the purchasers are not unfairly burdened. The developer should not only provide for this arrangement in the charter, but should also sign an agreement with each purchaser and the board of managers. A similar arrangement must be made where a home owners association is utilized.

Allocating the right to vote unsold units involves a similar problem. It is not feasible to allocate voting power based on the number of unsold units, where the number of units contemplated for the entire development is unknown. On the other hand, allocations based solely on the number of units already developed means that the developer who proposes to construct the subdivision in five successive sections would retain control only until he sold the majority of the units in the one developed section. A balance must be struck between the developer's interests in enhancing the sales appeal of units yet unsold, and perhaps unbuilt, and the interest of existing unit owners who may not wish to be governed by the developer. Opposition by unit owners may be tempered by the reported experiences in a number of projects showing that extended control by the developer enhances the chances of the venture's success. ${ }^{81}$ The developer should be certain to disclose to the purchaser his power to control, especially where state blue sky laws are applicable, and he should not be overanxious to prolong his control, since this will increase his exposure to suits for misconduct in running the development. Although similar provisions must be made where a home owners association is utilized, there is ample precedent for the developer to retain broad voting powers under existing law ${ }^{82}$ and perhaps to differentiate the assessment obligations for unbuilt units. Un-

80 See note 60 supra; Rohan, Condominium Housing: $A$ Purchaser's Perspective, 17 Stan. L. REv. 842 (1965).

81 See, e.g., HANDBOoK, supra note 2, at 240.

82 See id. 241, 246. 
like the condominium, the developer's control over an association tends to be less irksome to unit owners, since the association's activities are traditionally limited largely to common facilities rather than to the homes themselves.

\section{G. Zoning and Multiple Dwelling Regulations}

A number of states provide that the zoning classification of a development shall not be altered merely because it utilizes the condominium format. 83 In other states, condominiums may sometimes be used to advantage to avoid zoning restrictions, although they have in the past encountered zoning difficulties. ${ }^{\text {st }}$ For example, where all of the condominium units (together with the commonly owned portions such as walls, roofs, and land underlying the units) are regarded under local law as one large unit for zoning purposes, individual units may not be required to comply with zoning provisions regarding side yards or lawns; the developer may also be able to sidestep a requirement that each unit face a street, opening the possibility of constructing units in the interior of the tract or facing parkways. If a local law permits more multiple dwelling units than separate private homes to be erected on a given plot, the restrictions on the number of homes which may be constructed on the tract may be avoided if the condominium is regarded as one large multiple dwelling. ${ }^{85}$

The certificates of occupancy issued for these attached developments have sometimes classified them as multiple dwellings. In some instances, this can boomerang and force compliance with sections of the multiple dwelling codes that require a resident manager, special peepholes in doors, fire exits, and intense lighting in hallways. ${ }^{s 6} \mathrm{Mul}-$ tiple dwelling classification seems inapposite for lateral developments where each home is physically separated, resembling ownership of a conventional one-family home. Another disadvantage of such a classification is that any building code violation existing in only one unit may be noted as a violation for all units causing other owners difficulty when they desire to sell their units. It is likely, however, that local officials, who traditionally are not as zealous in enforcing the correction of violations in private homes as in rental housing, will also take this liberal attitude with lateral condominium subdivisions.

83 See Alaska Stat. \$34.07.440 (Supp. 1968); Fla. Stat. ANN. \$711.21 (1969); IdAHo Code ANn. \$55-1527 (Supp. 1967); MD. ANN. Code art 21, \$140 (1957); Nev. Rev. Stat. \$117.110 (1965); Tex. Rev. Crv. Stat. art. 1301a (Supp. 1968).

84 Armstrong \& Collins, Condominiums-The Magic in a Word, 16 So. CaLIF. TAx. INST. 667, 677-78 (1964).

85 See Offering Plan for Elmwood at Bayside, New York (1966).

86 See N.Y. Mult. Dwell. Law $\$ \S 35,50-a, 53,83$ (McKinney Supp. 1968). 
Where appropriate, therefore, the developer can claim that the project is a multiple dwelling, permitting construction of more units than would otherwise be possible. When classification as a multiple dwelling would be disadvantageous, he can insist that the units were one-family dwellings. Home owners association developments will, of course, be unable to obtain such zoning advantages, but will avoid classification as a multiple dwelling because of the physical separation between the common and privately owned areas.

However, it is unlikely that such advantages will be long lived, since two of the main purposes of zoning are inapposite to this treatment: limiting the population density and retaining beneficial aesthetic characteristics of a neighborhood. Local officials will probably become aware of such practices and either modify the zoning codes to prevent such evasion or interpret them restrictively.

Use of a corporate entity by a developer who is planning to own and manage extensive recreational facilities may not be possible where local officials are fearful that the municipality will have to take over maintenance at its own expense if the corporation does not adequately maintain, or actually abandons, these facilities. Local officials may, therefore, prefer that the development be in the condominium or some other noncorporate form that makes all owners personally responsible. In some cases, this obstacle may be overcome by a bond to cover possible maintenance expenses.

\section{H. Blue Sky Regulation of Sales}

Some states subject the offer and sale of condominum units to stringent regulation, the most demanding of which require the developer to register his offering, causing a delay of several months until registration is cleared. ${ }^{87}$ Sizeable filing and inspection fees are sometimes required, ${ }^{88}$ and large legal and accounting fees are often necessary for the preparation of the registration statements and supporting materials, and for legal representation before the regulating agencies. All too often, the registration process forces the developer to modify his plans to satisfy the agency, ${ }^{89}$ resulting in a loss of sales due to both the delay in selling until completion of registration and to state disclosure requirements. The developer may also be required to place a large por-

87 See Cal. Bus. \& Prof. Code $\$ 11010$ (West Supp. 1968); Hawalr Rev. Stat. \$514-34 (1968); N.Y. GEN. Bus. LAW \$352-e (McKinney 1968), as amended, N.Y. GeN. Bus. LAw § 352-e (McKinney Supp. 1968).

$88 I d$.

89 See Cary, Why I Oppose the Divorce of the Judicial Function from Federal Regulatory Agencies, 51 A.B.A.J. 33 (1965). 
tion of the proceeds of sale in trust. ${ }^{.0}$ Other states, while regulating offerings and sales of condominium units, make less stringent demands. ${ }^{01}$

By using the home owners association format, a developer may be able to reduce or avoid altogether these difficulties, at least until the current enforcement attitudes of local officials change. In New York, although condominium developments are subject to extremely strict and sometimes onerous regulation, developments utilizing a home owners association framework have in practice been subjected only to the more liberal subdivision laws, although the blue sky statute ${ }^{82}$ purports to subject all kinds of "cooperative interests in realty" to state regulation, whether or not the traditional cooperative corporation format is employed. Other states also supervise home owners associations less stringently. ${ }^{93}$ Confusion exists when lateral condominium developments are regulated by both subdivision laws and condominium statutes. This anomalous situation exists because the drafters of condominium legislation associated condominiums solely with high-rise structures, rather than with lateral developments already regulated under the subdivision laws. The exception is California, where developments are subject to the same regulations whether they employ the condominum or home owners association framework. ${ }^{94}$ The California pattern is likely to prevail in the long run, thereby eliminating any advantages that home owners associations presently enjoy in this respect.

Registration of condominium offerings with the United States Securities and Exchange Commission is governed by the same principles applicable to offerings of stock with appurtenant apartment leases in cooperative housing. While the absence of either a profit motive or risk may not itself determine whether an interest is a security, ${ }^{95}$ the absence of both of these factors in the purchase of stock relating to a cooperative apartment has resulted in its being regarded as an interest in real estate rather than securities. ${ }^{96}$ Consequently, the SEC has

90 See statutes cited in note 87 supra; Offering Plan for Leisure Village, New Jersey at $55,56(1965)$, requiring money to remain in escrow until the completion of all units ultimately planned for the development over a period of years.

${ }^{01}$ See, e.g., VA. CODE ANN. $\$ \$ 55-79.2,55-79.17,55-79.23$ (1969).

92 N.Y. GEN. Bus. LAW \$352-e (McKinney 1968), as amended, N.Y. Gen. Bus. LAW \$352-e (McKinney Supp. 1968).

83 See Alaska Stat. \$34.07.060 (Supp. 1968) ; Idamo Code Ans. \$§ 55-1525, 55-1527 (Supp. 1967) ; Mich. Codrp. Laws \$ 559-29 (1967) ; Nev. Rev. Stax. \& 117.120 (1963); WASH. REV. CODE ANN. \$64.32.110 (1966). No other states specify that subdivision regulations apply to condominium developments.

94 See Cal. Bus. \& Prof. Code $\$ 11010$ (West. Supp. 1968).

95 See SEC v. C. M. Joiner Leasing Corp., 320 U.S. 344 (1943) ; Silver Hills Country Club v. Sobieski, 55 Cal.2d 811, 815, 361 P.2d 906, 908, 13 Cal. Rptr. 186, 188 (1961) (rejecting a profit-motive test while emphasizing the risk element as being determinative of the nature of the interest); Coffey, The Economic Realities of $a$ "Security": Is There a More Meaningful Formula?, 18 W. RES. L. REv. 367, 381, 400 (1967).

go 1 L. Loss, Securities Regulation $492-94$ (2d ed. 1961). 
exempted offerings of $\$ 300,000$ or less pursuant to rule $235,{ }^{97}$ and in fact has been issuing no action letters even where offerings have exceeded $\$ 300,000 .^{98}$ Since condominiums and home owners association developments share these risk and profit characteristics with cooperative apartments, they should be entitled to the same treatment. They have additional merit in that no certificates of stock are issued. The undivided interest of each condominium unit owner in the common elements is also a real property interest and should not affect the exemption from registration requirements. ${ }^{90}$

\section{Leased Lands}

A developer in the market for a suitable tract may find that the owners of the best or cheapest land available refuse to part with title, but are willing to lease the land on a long term basis. Similarly, a developer may desire to retain title to the land or to the recreational facilities and rent them to the unit owners. Anomalous situations develop in states like Florida where most of the condominiums have been developed on leased lands, although the state attorney general has held that the statute requires fee ownership. ${ }^{100}$ The many states ${ }^{101}$ that forbid construction of a condominium on rented land operate on the theory that a purchaser of a unit should not forfeit his investment if others do not contribute enough to pay the "rent" for the underlying leasehold. Such provisions may be overly protective since owners could be protected by a provision in the lease limiting the forfeiture to the defaulting unit owner.

\section{Problems for the Unit OWNers}

Where reasonably priced lateral developments with common facilities are constructed using either the home owners association or con-

9717 C.F.R. $\S \S 230,235$ (1968).

98 Interview with John Hanghan, of the SEC Chief Counsel's office, June 26, 1968. See Offering Plan for the St. Tropez Condominium, New York (1965) for $\$ 14,285,000$ which was not required to be registered with the SEC.

Where, however, there may be substantial risk of loss or expectation of profit by purchasers, registration may be required. Mincolla v. Arthur-Hardgrove Co., Civil No. 65, (S.D.N.Y. 1965). Risk has been found to exist where units are offered in a housing development that has not yet been completed. See Hoisington, Condominizuns and the Corporate Securities Law, 14 Hastrngs L. Rev. 241, 252 (1963); Sobieski, Securities Regulation in California: Recent Developments, 11 U.C.L.A. L. REv. 1, 7-8 (1963).

$99 \mathrm{H}$. Bloomenthal, Cases and Matertals on Securities Law 76 (1966).

100 [1963-1964] Fia. Atr'y Gen. Biennial Rep. 064-20, 064-62. See McCaughan, The Florida Condominum Act Applied, 17 U. FLA. L. Rev. 1, 28-29 (1964).

101 See Minn. Stat. Ann. \$ 515.02, subd. 14 (Supp. 1969); N.Y. Real Prop. LaW \$ 339-e (11) (McKinney 1968); W. VA. CoDE ANN. \$ 36A-1-2(p) (1966).

For statutes defining "property" as including interests in addition to a fee simple, see AlasKa Stat. § 34.07.450 (13) (Supp. 1968); HawaIr Rev. LaWs § 170A-2 (r) (Supp. 1963). 
dominium format, some of the overall objectives outlined at the beginning of this Article may be attained. Both can encourage the proliferation of home ownership, which will enhance the status of purchasers, and both are designed to afford relief from common home ownership chores, such as maintenance, repairs, and snow removal. Either institution can provide uncrowded private recreational facilities near the home which the unit owner could otherwise not afford. Each offers the financial benefits of a hedge against inflation, separate tax assessment, individual home mortgage, and the insulation of the owner from the defaults of others. Each purchaser will likewise have a voice in central management and a proportionate control of the affairs of the development.

Nevertheless, significant differences in the effect of these forms of development on the unit owners remain. Because of the detailed legislation enacted for condominium housing, there is a distinct variance in the effectiveness of these two formats in achieving certain desired overall goals.

\section{A. Independence and Privacy}

One of the great disadvantages of any form of common ownership is the sacrifice of independence by each participant; collective decisions of the housing community regarding management, standards of maintenance and services, improvements, and a wide range of other aspects of communal living will prevail over the desires of any individual homeowner. This stifling of individual freedom of action is part of the cost of acquiring a residence in densely populated urban areas where there is an acute scarcity of land. The interdependence of the units located in one building, using the same heating system, hallways and elevators means that misconduct by any apartment owner will have disastrous effects upon the others. Consequently, it may be desirable to utilize the condominium format in order to regulate closely the use of the apartments, as well as the common areas.

Drafted to make such high-rise developments feasible, ${ }^{102}$ the condominium statutes accordingly envisage wide-spread supervisory management and control by the condominium organization. Thus, the central management is required to repair common areas, ${ }^{103}$ which in most states include areas limited to a particular unit owner. ${ }^{104}$ Indeed, many jurisdictions have indicated that attempts to limit the areas of common ownership and supervision will result in disqualification of the

102 See text accompanying note 22 supra.

103 See Ill. Ann. Stat. ch. 30, § 318(f) (Smith-Furd 1969) ; N.Y. Prop. LAW \$339-cc (McKinney 1968); PA. Stat. AnN. tit. 68, $\$ 700.306(1)$ (1965).

104 See Alaska Stat. \$34.07.450(11) (Supp. 1968); Fla. Stat. Ann. § 711.03 (11) (1969); HaWAII Rev. LAWS $\$ 170 A-2(m)$ (Supp. 1963). 
development as a condominium complex..$^{105}$ It is common, therefore, to find that walls, roofs, and basement slabs of one family homes, commonly regarded as physically part of the unit, are included in the common areas. ${ }^{106}$ Since each home owner is obligated to contribute to the maintenance of these areas, he may also be required to pay for abuse or neglect of property by others. Similarly, alterations and improvements of units are severly restricted and may require the consent of the other owners. ${ }^{107}$ Decisions of the owners to improve the development or increase the standards of service can result in larger assessments which a dissenting owner, who has no right to have his unit appraised and purchased by the others, ${ }^{108}$ will be obliged to pay.

The wide-spread powers of collective management, with their inherent limitations upon individual freedom of action, are understandable, and perhaps necessary, in high-rise condominium developments because of the close physical proximity of the units. A lateral development, however, can present a completely different picture. The homes may be completely detached from one another with each unit built on a different plot of ground, with its own roof and unit walls, and its own heating system; the only areas used in common might be recreational facilities, lawns, parking space and walkways. In these cases, it would appear appropriate to amend the condominium statutes to permit the restriction of common ownership and management to those areas physically used in common, without subjecting the homes themselves to collective regulation.

Currently, this goal can be accomplished without new legislation by using a home owners association whose operations could be confined largely to the common areas that it owns. In this system each owner is responsible for the maintenance and repair of his own unit and does not suffer from the delinquency of others, and there is much greater freedom to alter and improve the home (subject to broad architectural controls), since such improvements are not likely to have a physical impact upon a neighboring unit. Similarly, each unit is freed of the obligation to use and pay for community services voted for by other owners except to the extent that he desires. In a democratic society where human dignity, privacy, and freedom from interference are desired goals, the present condominium format may be singularly inap-

105 RoHAN \& RESKIN, supra note 15, \& 13.02[2], at 13-7 (1968).

106 See, e.g., Offering Plans of Valley Towne Houses at Valley Stream, N.Y., of Leisure Village, Lakewood, N.J. and of Elmwood at Bayside, N.Y.

107 See Alaska Stat. \$34.07.370 (Supp. 1968); N.M. Stat. ANN. \$70-4-8 (Supp. 1967) ; N.Y. ReaI Prop. LAW \$339(k) (McKinney 1968) ; P.R. Laws ANN. tit. 31, §1291(p) (1967).

22 (1965).

108 Berger, Condominium Primer for Fiduciaries, 104 TRUSTs \& EsTaTeS 21, 
propriate for lateral developments. The condominium can, however, be fashioned into an effective instrument for achieving these objectives by statutory modification. ${ }^{100}$

\section{B. Mortgaging}

In the lateral condominium development, and more so in the highrise variety, existing legislation imposes pervasive collective management, making it impossible for a mortgage lender to rely solely on the integrity and financial record of the individual borrower. The value of each unit is dependent to a large extent on how the unit and its appurtenant common elements are maintained by the condominium organization. Consequently, many potential mortgage lenders are loathe to invest in construction or permanent mortgages, particularly where the development does not utilize professional management. Those who do lend may insist on control of the vote of the unit mortgagor or on veto powers. ${ }^{110}$ Since a unit may be subject to substantial assessment for repair of common facilities, including those limited common elements that are physically a part of another unit, or for the purchase of additional units, ${ }^{111}$ the mortgagee fears the imposition of a substantial assessment after he forecloses his unit mortgage. He also fears that the mortgage (which covers an undivided interest in the common areas in addition to the unit itself) will terminate if the condominium framework is abandoned, frustrating the long term investment goals of the lending institution. These hazards, together with the fact that condominiums are a strange new breed, make it difficult to obtain mortgages for units in a condominium development when money is tight. ${ }^{112}$ In some areas, only a few lending institutions will grant condominium mortgages. ${ }^{113}$ Of course, this difficulty in obtaining mortgages may discourage developers from promoting condominium complexes.

In a development using the home owners association, the scope and effect of which is restricted to common areas, there is little fear of an assessment for the repair of units, and less uneasiness about possible dissolution of the association, since unit mortgages do not cover common areas. It is therefore likely that for some time to come lenders will issue mortgages more freely for units affiliated with home owners

109 Suggested statutory changes in pt. IV infra.

110 See RoHAN \& RESKIN, sipra note 15, \$13.02[4], at 13-12 (1968).

111 See text accompanying notes 102-06 supra.

112 See Berger, The Condominiun-Cooperative Comparison, N.Y. CITY BAR Ass'N Symposiun of the Practical Problems of Condominium 34 (1964). See also ProceEdings, supra note 9, at 19.

113 In New York State, for example, condominium mortgage loans are currently granted primarily by. Dime Savings Bank and Williamsberg Savings Bank. See, e.g., Offering Plans of Kingswood Gardens, Valley Towne Houses, and Howard Beach. 
associations. Purchasers will also find it more difficult to obtain second mortgages on condominium units, because the statutes commonly provide that the liens for common charges levied by the organization are superior to the liens of second mortgages. This priority means that a purchaser is unable to obtain full benefit of his equity. ${ }^{114}$ With a home owners association, the developers and unit owners clearly have the freedom to decide whether or not the association lien shall have priority over second mortgages. The condominium may, however, be made more attractive to mortgage lenders by amending legislation to make the unit less dependent on central management for its physical maintenance, and to permit the unit mortgage to remain in force upon the unit in the event the condominium framework is abandoned.

Although a mortgage tax upon the first sale of a unit may be avoided in condominium developments, ${ }^{115}$ it is not a great advantage. The same result may often be obtained for conventional subdivisions by dividing the blanket construction mortgage into separate mortgages for each unit, and, if necessary, assigning it to the permanent mortgage lender.

Purchasers should be aware of other disadvantages of the condominium. The owner's unit, together with his interest in the common elements, is subject to a mortgage that requires that both be maintained properly. If waste is committed to the common elements the unit owner cannot afford. (and may legally be unable) to prevent or repair the damage, while the mortgagee may be permitted to foreclose the mortgage. There also is no feasible way to finance improvements of the common areas. Each unit mortgage covers an undivided interest in the common facilities and blanket mortgages are commonly prohibited. Because liens cannot be imposed on these areas without the unanimous consent of all owners and mortgagees, ${ }^{116}$ it is difficult to finance modernization of these facilities. Where the home owners association is utilized, mortgage financing is more feasible, although mortgaging the common areas in condominiums is possible if the statutes are amended.

\section{Insurance Coverage}

In order to increase the attractiveness of a high-rise condominium development, the developer may procure fire and liability insurance

114 See RoHAN \& RESKIN, supra note 15, \$13.02[4][b], at 13, 12; Wisner, Financing the Condomininu in New York: The Conventional Mortgage, 31 AldaNy L. REv. 32, 43 (1967). See also Berger, Condominium: Shelter on a Statutory Foundation, 63 ColuM. L. Rev. 987, 997 (1963).

115 See N.Y. Real Prop. LaW \$339-ee(2) (McKinney 1968).

116 See N.Y. REAL Prop. LaW \$ 339-1(1) (McKinney 1968); Wisner, Financing the Condomininm in New York: The Conventional Mortgage, 31 AlbaNY I. Rev. 32, 42 (1967). 
covering all units and common elements for his purchasers. Since the common elements and the individually owned units are in close proximity (often the walls and ceilings of the units are common elements), a fire to one will frequently damage the other. If each unit were covered by a separate policy, there would be problems of proration of insurance proceeds to repair the fire damage. To avoid complications it is generally thought advisable to provide for one blanket policy covering the sometimes conflicting interests of all unit owners and all unit mortgagees, but this arrangement too causes complications. ${ }^{117}$ It may also, as a practical matter, require the retention of an independent trustee to receive the insurance proceeds and represent all of the varying interests.

In a lateral condominium development there may be less physical proximity of units to common elements, since it is possible to arrange for each unit to include all of the features commonly thought of as physically part of the unit; the common elements could be limited to those facilities actually used in common by more than one owner. Apportionment problems can be avoided by having separate policies, each covering only one unit, with a distinct policy covering the common elements.

Even in a townhouse development where units share a common wall and roof, this approach may be desirable, although some problems remain. Each unit could be defined to include the roof above it, as well as a few inches of the common wall. Therefore, a fire in one unit might not damage any adjoining unit or common element. This approach may raise other difficulties, however, since an attempt to include roofs, outside walls, floors, and lawns as part of the unit may result in the refusal of governmental agencies to recognize the applicability of the condominium statutes to the development. ${ }^{118}$

Where the development utilizes the home owners corporation instead of a condominium for lateral developments, each owner can take out his own insurance policy, covering both fire and liability, in precisely the same manner as the owner of a house in a conventional development. The only difference would be that the corporation would take out a separate policy for any facilities which it owns. Therefore, the use of the corporation presents only a minimal number of problems regarding proration of insurance proceeds and coverage, and use of such proceeds for reduction of mortgage or repair.

117 See Rohan, Drafting Condominnm Instruments: Provisions for Destruction, Obsolescence and Eminent Domain, 65 CoLun. L. Rev. 593, 597-98 (1965); Rohan, Disruption of the Condominium Venture: The Problems of Casualty Loss and Insurance, 64 ColuM. L. REv. 1045, 1061-67 (1964).

118 See text accompanying note 105 supra. 


\section{Regulating the Conduct of Unit Owners}

A sine qua non for the viability and efficient operation of communal facility housing developments is the enforceability of the rules, regulations, and decisions of central management. This aspect may involve equitable sharing of common facilities and collections of expenses; preservation of the character of the common areas and prevention of their partition or severance from home ownership in the community; and setting architectural and land use controls to retain the beauty and harmony of the units and to prevent their occupancy for multi-family or non-residential purposes. ${ }^{119}$ Most state condominium statutes contain potent weapons for enforcing decisions and promoting these goals, including personal liability of the unit owner.

Where a home owners association is employed without such statutory powers, the ability to achieve these ends rests on shaky grounds. These controls and assessments must be made enforceable by the association, as such, and made binding not only on owners, who acquired their homes from the developer, but also on their successors, who may not have personally agreed to abide by such controls. Although agreements of unit purchasers to comply with decisions can be recorded as covenants running with the land in favor of the entity owning or managing the Overall Common Areas, they may have substantial drawbacks. The English courts, beginning with Spencer's Case, ${ }^{120}$ have held that such covenants would not be enforced against subsequent (nonsigning) owners personally unless there was, among other things, privity of estate between the parties (implying a landlord-tenant relationship), and unless the covenants "touched and concerned the land." The covenants would not, therefore, run against new owners. Later the British courts held that a court of equity would enforce restrictive covenants on the equitable ground that those who take with notice of a covenant cannot in good conscience be permitted to violate it; ${ }^{121}$ however, they refused to enforce affirmative covenants. ${ }^{122}$

American courts have generally held that affirmative covenants could run with the land and be enforced, ${ }^{123}$ although there is a division of authority whether or not covenants will be enforced by mandatory

119 See Berger, Condominium: Shelter on a Statutory Foundation, 63 CoLUM. L. REv. 987, 1010-12 (1963).

120 Spencer's Case, 77 Eng. Rep. 72 (K.B. 1583).

121 Tulk v. Moxhay, 41 Eng. Rep. 1143 (Ch. 1848).

122 Haywood v. Brunswick Perm. Benefit Bldg. Soc'y, 8 Q.B.D. 403 (1881).

1232 A. Casmer, Amertcan Law of Property $\$ 9.36$ (1952); See, e.g., Everett Factories \& Terminal Corp. v. Oldetyme Distillers Corp., 300 Mass. 499, 503-04, 15 N.E.2d 829, 832 (1938); Whittenton Mfg. Co. v. Staples, 164 Mass. 319, 328,41 N..E. 441,445 (1895). 
injunction and personal judgment, with very few decisions actually upholding such relief. ${ }^{124}$ In New York, it was originally held that affirmative covenants would not run at law or in equity. ${ }^{125}$ Subsequently, the New York courts held that covenants requiring payment of maintenance assessments would be enforced because they "touched or concerned" the land, and there was privity of estate between the association which sought to enforce the lien and the defendant homeowner. ${ }^{128}$ New Jersey courts, on the other hand, have refused to grant mandatory injunctions for enforcement of a covenant and have implied that there is no personal liability and no charge against the land. ${ }^{127}$ In California, recorded affirmative or restrictive covenants appear to be enforceable by statute, ${ }^{128}$ or as equitable servitudes even in the absence of statute. ${ }^{12 \theta}$ Nevertheless, the California legislature felt it necessary to enact additional legislation ${ }^{130}$ providing that the powers of the board of managers of the condominium shall be enforced as an equitable servitude, because of serious questions as to their enforceability in the absence of such additional legislation. ${ }^{131}$ There is equal uncertainty about enforcing decisions of collective management as an equitable charge creating a personal obligation, or a negative easement. ${ }^{132}$ Consequently, in some states a home owners association is unable to enforce the payment of its assessments or the repair and maintenance of the unit as a personal obligation of the unit owners.

124 See HANDBOOK, supra note 2, at 315-20; Note, Organizing the Tozenhouse in Indiana, 40 IND. L.J. 419,435 (1965). See generally 2 A. CASNER, AMERICAN LAW OF PROPERTY, $\$ 9.4$ (b) (1952).

125 Miller v. Clary, 210 N.Y. 127, 132-37, 103 N.E. 1114, 1116-17 (1913).

126 Neponsit Property Owners' Ass'n v. Emigrant Indus. Sav. Bank, 278 N.Y. 248, 262, 15 N.E.2d 793, 798 (1938); see Lawrence Park Realty Co. v. Critchton, 218 App. Div. 374, 218 N.Y.S. 278 (1926). Nicholson v. 300 Broadway Realty Corp., 7 N.Y.2d 240, 164 N.E.2d 832, 196 N.Y.S.2d 945 (1959), followed the Neporsit rule but did not discuss whether there existed privity of estate.

127 In Furness v. Sinquett, 60 N.J. Super. 410, 416-17, 159 A.2d 455, 458-59 (1960), the court stated:

The apparent dearth of cases dealing with affirmative covenants in our State and others, as contrasted with the multitude of cases concerned with restrictive or negative covenants, clearly shows the reluctance of our courts to enforce them, as a consequence of which property owners have not attempted to control the uses of their lands by their inclusion as conditions or restrictions.

128 CAL. Crv. Code $\$ 1462$ (West 1954). Similar provisions appear in Fla. Stat. AnN. \$711.08(3) (Supp. 1969): Miss. Code ANN. \$ 896-09 (Supp. 1A, 1968).

12914 CAL. Jur. 2d Covenants, Etc. \$\$102-11 (1954); see Comment, Control and Management of Common Elements by Covenant, 14 HASTrNGS L.J. 309, 311 (1963); Comment, Conmmutity Apartments: Condominim or Stock Cooperative?, 50 CaIIr. L. REv. 299, 321-22 (1962).

130 Cal. CIv. Code $\$ 1355$ (West Supp. 1968). (1963).

131 See Gregory, The California Condominium Bill, 14 Hastrngs L.J. 189, 198

${ }^{132}$ See HANDBOOK, supra note 2, at 316 (equitable charge), 311 (negative easement). 
Default in executing covenant provisions may result in loss of membership in the separate entity, but this may not be sufficient to assure compliance. Foreclosure of the liens on the units created by the covenants may also be ineffective, since assessment liens may be subordinate to liens of recorded mortgages, taxes, and common charges established by an Overall Entity for the individual sections of the development and homestead exemptions. Hence, little is left for the enforcement of the association covenants. While it is possible to arrange for the assessment lien to have priority over mortgages, ${ }^{133}$ such an arrangement would make the homes unattractive to mortgage lenders. Assessment liens, therefore, are subordinated to mortgages even in condominium statutes. ${ }^{134}$ In most cases, however, it is likely that a home owner's equity investment will be ample to provide adequate leverage for enforcement of the covenant liens. It would also be a simple matter to further assure the validity of the covenants by providing in unit mortgages that violations of the covenants constitute a mortgage default as well, thus permitting foreclosure.

These provisions may also be inserted in the deed to each home as a condition subsequent with a power of termination. The covenants might also be incorporated in a second mortgage on each home in favor of the association. There appears to be no reason why the controls should not be enforceable against subsequent acquirers of the homes like any other mortgage, thus avoiding any limitations which may exist in enforcing covenants, equitable servitudes, and negative easements. Personal liability of subsequent owners may also be procured by proper provisions in the association mortgage.

The condominium developer may be unable to avoid using covenants, if he wishes to subdivide a large tract in stages. He may have to rely on such covenants rather than on the condominium statutes in order to assure the use of the recreational facilities located in one section to the owners of the units in other sections, and to enforce decisions of the central organization which manages or owns the common facilities. It would therefore appear that as a practical matter there is little difference between the condominium format and the home owners association in the enforcement of assessment collections or unit maintenance and repairs.

A related problem exists in controlling resales of homes by affording the association a right of first refusal or otherwise restraining alienation, which may be in violation of law. ${ }^{135}$ Some condominium

133 See Prudential Ins. Co. of America v. Wetzel, 212 Wis. 100, 102-03, 248 N.W. 791, 792 (1933).

134 See, e.g., N.Y. Real Prop. IAw \$339-z (McKinney 1968).

135 See Berger, Condominium: Shelter on a Statutory Foundation, 63 Colum. L. REv. 987, 1017-19 (1963). 
statutes permit such restraints, ${ }^{136}$ providing an advantage over the home owners association format, but such controls can be quite irksome to the owner who desires to alienate.

\section{E. Personal Liability of Purchasers}

In a condominium development, each unit owner has an interest in the common elements. Consequently, all may be legally liable for tortious injuries occurring there, for maintenance, repairs, and improvements of these areas by management, or for the performance of contracts entered into by supervisory personnel. ${ }^{137}$ Since the opportunities for law suits are manifold and ever present, this exposure of unit owners is hazardous. Even more onerous is the possibility that all owners may be liable for events occurring in areas which are technically common elements, but which are used and exclusively controlled by one owner, such as patios, walkways, and lawns. ${ }^{138}$ Exposure is heightened by the tendency to classify as common elements many portions of the structures which are physically part of the units, sometimes restricting fee ownership to little more than air space. ${ }^{139}$

The fact that all unit owners have undivided interests in the common areas may also lead to other unfortunate situations. A unit owner may be liable to third parties on matters that have no relation at all to the condominium development. Nevertheless, if judgment is obtained against him, all of his assets, including his interest in the common areas, will be subject to the judgment. Since his interest is undivided, the judgment lien will be placed against all of the common areas. This may initially cause title difficulties for other owners who desire to convey their units in the common areas free of such liens-at least until prospective purchasers (and their title insurers) become convinced that there is no danger of actual foreclosure of the lien against them, because the lien is not against their interests, and because the anti-partition provisions of the condominium statutes will, in any event, prevent the forced sale of the debtor's common interest without his appurtenant unit.

If home owners incorporate and convey title to the common areas to the corporate association, the liability problems of the home owners

136 See D.C. Code ANN. \$5-926 (1967) ; Irt. ANs. Stat. ch. 30, §320 (SmithHurd 1969); N.Y. REAL Prop. LAW \$339-v(2) (a) (McKinney 1968); R.I. GeN. LAWS ANN. \$34-36-28 (Supp. 1967) ; UTAH CoDE ANN. \$ 57-8-28 (1963); Roses, Condomintiums and Preemptive Options: The Right of First Refusal, 18 Hastrngs L.J. 585, 590-92 (1967).

137 See Berger, Condomininm: Shelter on a Statutory Foundation, 63 CoLvM. L. Rev. 987, 995; Kerr, Condomininm-Statutory Implementation, 38 ST. JoHN's L. REv. 1, $41-43$ (1963).

138 See RoHAN \& RESKIN, supra note $15, \S 10 \mathrm{~A} .05$, at 10A-12.

139 See 4 R. Powell, The Law of Real Property $\$ 633.19$ (1967). 
will be reduced. Since they will not own these common facilities directly, it is unlikely that they will be held liable for injuries sustained there, or for work performed at the request of management, except where circumstances indicate a principal-agent relationship, or where the courts would be willing to pierce the corporate veil. Similarly, liabilities of and judgments against a unit owner that are unconnected with his unit will have no effect on the common facilities owned by the corporate entity. In some states, the condominium organization may be in corporate form. ${ }^{140}$ But this still will not eliminate the unit owners' personal liability, since, under these statutes, the corporation would not own the common elements which would continue to be the property of the unit owners. ${ }^{141}$

The tort liability of condominium owners may, however, be covered by insurance protection. The coverage will effectively shift the burden of risk to the insurance company, unless there is a lapse in insurance coverage or the terms and conditions of the policy are not fulfilled. The owners can be further insulated from liability by organizing a corporation outside of the development's condominium framework to own and manage the bulk of the common facilities.

In a number of states, moreover, a unit owner's liability is limited by statute. ${ }^{142}$ But even this limitation will not completely immunize him from responsibility, since he may be liable in assessments for his share of any judgment obtained against the condominium entity. In other states, each owner may be liable for the full amount of any uncollectible judgment against the managing association. ${ }^{143}$ Some state statutes ${ }^{144}$ provide that all common charges collected shall be held as a trust fund to satisfy claims of lienors, which may mean that the operations of the development will be crippled until enough is collected to satisfy the debt, thus throwing the obligation on the shoulders of the unit owners.

Unless legislation is enacted exempting unit owners from personal liability for the common areas, as is true in the case of incorporated home owners associations, a non-profit corporation which would own the common areas appears to be a much more effective shield than the condominium format. However, corporate ownership would mean that unit owners, under present law, would be unable to take income tax deductions for realty taxes, casualty losses, and mortgage interest pay-

140 See Idaho Code Ann. \$55-1506 (Supp. 1967) ; N.J. Stat. AnN. § 46: 8A-27 (Supp. 1968) ; MAss. Gen. Laws ANN. ch. 183A, \&8(i) (Supp. 1968).

141 See text accompanying notes 171-179 supra.

142 See Alaska Stat. \$34.07.260(b) (Supp. 1968); Miss. Code ANn. \$ 896-15 (Supp. 1968); VA. Code ANN. \$ 55-79.37 (1969); WAst. Rev. Code ANN. § 64.32.240 (1966).

143 See, e.g., N.C. Gen. Stat. \$47 A-26 (1966).

144 See, e.g., N.Y. Real Prop. LAW §339-l(2) (McKinney 1968). 
able with respect to the common areas and might be unable to defer recognition of gain upon the sale of their homes. ${ }^{145}$

\section{F. The Nature of the Common Interest}

A condominium unit owner's voting power and share of common expenses are normally fixed by the "common interest" allocated by the developer to the unit. This reflects the confusion inherent in the use of the term common interest for three distinct purposes; (a) the amount of the distribution to each unit owner in the event of destruction, condemnation or termination, or sale of the development, (b) the extent of his voice in central management, (c) his share of common expenses.

It is inappropriate, when assigning a greater common interest to a higher priced unit, always to burden it with a greater share of common expenses. This is particularly true in lateral developments where the physical separation of the units makes it advisable to limit common expenditures to maintenance of common facilities equally available to all. ${ }^{146}$ Each unit owner could be responsible for the repair of his own unit as well as those portions of the common elements, such as the roof and outside walls, which are used exclusively by him.

Similarly, there is no reason why the sale price of a unit should always determine its voting rights. On the other hand, the establishment of the common interest in accordance with criteria other than price would be unfair to the owner of an expensive unit who might receive less than his equitable share of insurance proceeds in the event of destruction of the development. Some jurisdictions provide that the interest, voting power, and expenses shall be apportioned equally among all units, regardless of price, unless the condominium instruments provide otherwise. ${ }^{147}$ But this solution would result in similar inequity and would mean that all units would share expenses equally regardless of their size, unless, of course, the instruments stipulated otherwise.

145 See INT. REv. CoDE of 1954, \$§163(a), 164(a), 165; Rev. Rul. 64-31, 1964-1 Cum. Bull. 300. INr. REv. CODE OF 1954, $\$ 1034$ permitting deferral of gain is limited to the gain on the sale of taxpayer's "principal residence."

Where a taxpayer simultaneously realizes a gain on the sale of his interest in the property of the corporation, he would have the burden of proof in allocating a portion of the gain attributable to the residence. See Inaja Land Co., 9 T.C. 727 (1947). The developer, too, must make similar allocations. In order to compute his gain on the sale of a unit, he would have to allocate a portion of the cost of the common facilities to the unit, presumably based on the common interest appurtenant to the unit. Although a recent revenue ruling, Rev. Rul. 68-478, 1968 INT. REv. BuLL. No. 35 , at 34 , provides that the cost of recreation facilities cannot be added to the basis of units unless the developer parts with his ownership of the facilities, his retention of the interests appurtenant to unsold units should not prevent this, since he parts with the interests appurtenant to those units sold.

146 Text following note 108 supra.

147 Carif. Civil Code Ann. \$1353(b) (West Supp. 1968); Miss. Code Ann. § 896-07B (Supp. 1968); Nev. Rev. STAT. \$ 117.040 (2) (1965). 
A more desirable approach is found in the Florida statute, ${ }^{148}$ where different percentages are allowed for common interests, for shares of common expenses, and for voting. Thus, the percentage of interest in the common elements might be fixed in accordance with the price of the unit. If statutory specificity is desired, the law could provide that the common expenses be apportionable, as in France, ${ }^{149}$ according to the benefit derived by each unit from them, or where more equitable, apportioned equally among all units. Voting rights might also be allocated equally among all units while protecting the rights of the more expensive units by requiring a greater percentage of votes on specific items of major importance, such as improvements or the termination of the condominium. Where the difference in price between the cheapest and most expensive unit is minor, perhaps the simplest solution would be to allocate the same rights and obligations to each unit regardless of the price paid. This would greatly simplify the condominium structure, and would obviate many of the problems hereafter outlined.

Greater flexibility in allocation of the common interest is likely with a home owners association. The developer will not be faced with statutory restraints of condominium legislation and will be able to tailor his allocations of interests, voting rights, and expenses in accordance with the circumstances prevailing for the particular development. ${ }^{150}$

\section{G. Termination}

Where the unit owners decide to abandon the condominium format, existing legislation provides that both the units and common areas shall be owned in common by all the participants, any of whom can then force their partition and sale. ${ }^{151}$ Similarly, the condominium framework may be terminated if part or all of the property is destroyed or becomes obsolete and a specified percentage of unit owners do not vote to repair or modernize. ${ }^{152}$

Common ownership and forced sale of the units and common areas may be appropriate following a decision to dissolve a high-rise condominium structure. The physical interdependence of the units does not

148 Fla. Stat. ANn. \$711.08(1) (1969).

149 See Brown, French Co-Property of Apartments: A Model for English Law?,

110 SoL. J. 591 (1966).

150 HANDBOoK, supra note 2 , at 206-07, 346-50.

151 See Alaska STAT. $\$ \S 34.07 .330,34.07 .340,34.07 .270-290$ (Supp. 1968); FLA. Stat. AnN. \$\$711.16-17 (Supp. 1968); Mich. Comp. Laws \$ 559.9 (1967) ; N.Y. Real Prop. LAW § 339-t (McKinney 1967); VA. Code ANN. \$55.79.34 (1969).

152 See Cal. Civ. Pro. Code \& 752(b) (West Supp. 1968) ; Cal. Civ. Cone § 1354 (West Supp. 1968) ; Mrss. Code ANN. \$896.18 (Supp. 1968); OHIo Rev. Code ANN. $\$ 5311.15$ (Baldwin 1968); OrLa. Stat. Ann. tit. 60, § 528 (1967); Ore. Rev. Stat. $\$ 91.660(1965)$. 
make it feasible for each owner to retain his unit if part of the structure is destroyed or the condominium framework is otherwise abandoned. In lateral developments, however, there is no compelling reason to require the sale of all the units upon abandonment of the condominium organization. Even where termination results from the destruction of some of the units, the owners of the undamaged units could be permitted to retain them as home owners in a conventional development. Similarly, where insurance proceeds are to be paid for the destruction of units under blanket policies, it is quite inappropriate for the statutes ${ }^{153}$ to require distribution of proceeds among all unit owners according to common interests where the failure to vote to repair the damage causes the condominium format to come to an end; the proceeds should be handed over solely to the owners of destroyed units. Even where all units are destroyed, the common interest should not be the basis of allocation. The size of these interests is normally determined by their original sales price and frequently cannot thereafter be varied. ${ }^{154}$ Since the value of a unit in a horizontal development vis-a-vis the others may change because of improvements or superior maintenance by individual owners, it would be ludicrous to apportion the distributions according to the facts which prevailed many years before.

With a home owners association format, termination of the association raises the problem only with the common facilities, not with homes themselves. Since each home has its own insurance policy, its proceeds belong solely to the insured, and would presumably vary with changes in the value of the home. The proceeds from the sale or destruction of the common facilities could be distributed in accordance with the participation of each owner in the association based, perhaps, on the amount of his contribution to the association. Changes in the value of a home should not, therefore, affect the amount of his participation.

\section{H. Partial Destruction or Condemnation}

1. Repair of the Damage: Dissolution of the Condominium Establishments

The longer the condominium remains established, the greater the possibilities are for condemnation or destruction of some of the units or part of the common facilities. Partial destruction or condemnation

153 Ill. ANn. Stat. ch. 30, § 314 (Smith-Hurd 1969) ; MrNn. Rev. Stat. art. 30, $\$ 515.26$ (Supp. 1968); N.Y. REAL Prop. LAW \$399-cC (McKinney 1967); Ore. REv. STAT. \$ 91.660 (1968).

154 Some states allow the by-laws to provide for a different method of apportioning the distributions. See ConN. Gen. Stat. AnN. \$ 47-80 (Supp. 1968); MD. Ann. Code art. 21, § 135 (1957) ; N.J. Stat. ANN. \$ 46: 8A-24 (Supp. 1968); P.R. LAwS ANN. tit. 31, §1293(h) (1967); Tex. REv. Civ. Stat. art. 1301(a), \$\$20-21 (Supp. 1968). 
is more likely in a lateral development than in a high-rise development consisting of one building. ${ }^{155}$ Condominium statutes commonly require that destruction of any unit must be repaired by the board of managers. This statutory protection carries with it, however, the corollary obligation for owners of undamaged units to pay for rebuilding the destroyed unit. ${ }^{156}$ Where most of the units are destroyed, all the owners vote on whether or not to repair. If they do not consent to repair, the condominium organization is dissolved and the development must be sold, with the proceeds divided among all unit owners. ${ }^{157}$

This procedure may, perhaps, be appropriate in a high-rise condominium apartment house where damage to units and common areas in one portion of the building may mean that the remaining units cannot continue to function in a partially destroyed structure. In a lateral development, however, where the units are physically separate, the development can continue to operate even though the destroyed units are not restored. It is therefore unnecessary to bind the fortunes of all unit owners to one another, and to penalize the owners of undamaged units by requiring them to pay for the reconstruction of units which do not belong to them. This is especially true if the fire was due to the negligence of the owner of the unit destroyed, and is equally applicable in garden apartment condominium developments. Moreover, in lateral complexes, it may be feasible for each unit to be covered by a separate casualty insurance policy, ${ }^{158}$ which would provide adequate proceeds to repair the fire damage. Failure by the owner of any damaged unit to maintain such coverage should not result in the imposition of a penalty on the other owners. It is also inappropriate for the condominium legal superstructure to be dissolved upon the failure of unit owners to repair, ${ }^{159}$ or to permit owners of undamaged units to decide the fate of the damaged ones. ${ }^{160}$

155 Partial destruction or condemnation can, of course, also occur in a high-rise development consisting of more than one building or containing recreational facilities located outside the residential structures. Although many of the statutes talk about destruction of "the building," because of their high-rise orientation, it is presumed that this language will be interpreted to include all of the structures where the development consists of many buildings. This has been the assumption made in a number of developments. See PA. STAT. ANN. tit. 68, $\$ 700.802$ (1965); Declaration of the Atlantic Cloister Condominium Boca Raton Florida, \$ 5.1(b) ; Rohan, Drafting Conaominium Instruments; Provisions for Destruction, Obsolescence, and Eminent Domain, 65 Colum. L. REv. 593, 600 (1965).

150 See Rohan, Disruption of the Condominium Venture: The Problenns of Casualty Loss and Insurance, 64 ColUM. L. REv, 1045 (1964). Some statutes provide that only the owners of units "directly affected" by the destruction must pay for the cost of repair. E.g., ARK. Stat. ANN. § 50-1022 (Supp. 1967); N.J. Stat. ANN. § 46: 8A-25 (Supp. 1968); P.R. Laws ANN. tit. 31, \$1293(i) (1967); Tex. Rev. Civ. Stat. art. 1301 (a), \$21 (Supp. 1968).

157 Text accompanying note 151 supra.

158 Text accompanying notes $118-19$ sipra.

159 Text accompanying note 157 supra.

160 Text accompanying notes $156-57$ supra. 
These problems can be met more readily by home owners associations, where the developer is free to insulate each owner from liability in the event of destruction of other units, and to vest the decision and responsibility for reconstruction in the hands of the owner of the damaged unit. Where appropriate, the developer can provide in the legal instruments for the continuance of the development in the event of partial destruction.

\section{Contraction of the Development}

When some units of a lateral development are destroyed, and the complex continues to function, it should logically follow that the owners of the destroyed units should no longer participate in the condominium or have a vote in its affairs. Furthermore, they should also be released from any future obligation to pay common charges. In return, provision must be made for the owners of destroyed units to surrender their undivided interests in the common areas. At the same time, the interest of the owners of the remaining units should be increased. But such a solution runs head on into the inflexible condominium statutory provision prohibiting changes in the common interests without the consent of all owners; if any one owner objects or fails to consent to such reallocation, it cannot be carried out. Unfortunately, there are only a few states that permit a contraction of the condominium. ${ }^{\mathbf{1 6 1}}$

Even if a reallocation of common interests is possible, the further problem arises of what the basis of the new common interests should be. The original sales prices may be irrelevant because the relative value of the units in a horizontal development may be very different from the original prices, due to varying maintenance or extensive improvements of units by unit owners. Values may even have changed because of the location of units; deterioration of adjoining neighborhoods outside the condominium development may affect the value of adjacent units more than that of more remote units. It is desirable that reapportionment of common interests be based on conditions prevailing at the time of such change rather than those which existed when the units were first sold.

Moreover, the elimination of the destroyed units and the reallocation of their interests in the common elements is a technical severance of these interests from the appurtenant units, which is expressly

161 New York provides for contraction in the event of condemnation; other states permit contraction in any event upon vote of the unit owners. See HaWAII Rev. STAT. tit. 28, § 514-17 (1968); Mass. ANN. LAWs ch. 183A, § 19(a) (Supp. 1968); N.Y. REAL Prop. LAW \$339-i(2) (McKinney 1968); OKLA. STAT. ANN. tit. 60, §\$ 527-28 (Supp. 1967); PA. Stat. ANN. tit. 68, §700.802 (1965); W. VA. CodE ANN. \$36A-8-2 (1966); Schwartz, Condominimm: A Hybrid Castle in the Sky, 44 B.U. I. REv. 137, 151 (1964). 
forbidden by the condominium statutes. ${ }^{162}$ It might be argued that since these statutes bar partition of the common areas, localities are thereby forced either to condemn all of the common elements or none, since partial condemnation effectively severs the taken areas from the other common elements, violating the statutory ban on partitions. However, such limitation on the power of condemnation was probably unintended, and is therefore not likely to be implicit in the statutes. ${ }^{163}$

Partial condemnation of a condominium development causes problems similar to those of partial casualty. The difficulties are exacerbated, however, since most statutes are silent regarding condemnation. ${ }^{104}$ This silence is consistent with similar omissions in the Puerto Rico and FHA model acts, which did not contemplate that the costly new high-rise developments would be condemned. ${ }^{165}$ Without specific statutory guidance, courts may apply to condemnation some of the statutory provisions covering destruction. Statutory amendment is, therefore, necessary to resolve the foregoing problems and to prevent the condemning governmental agency from becoming a participating owner in the development with the right to vote and duty to pay a portion of assessments that will thereafter be levied.

Home owners associations can, of course, easily provide in their charters and by-laws for a contraction of the organization by eliminating owners of destroyed or condemned units, with voting power and maintenance obligations allocated equally among remaining unit owners. Since there is no statutory prohibition regarding severance of the common elements, there will be no problem of forbidden partition as in the case of condominiums, even where a condemnation includes a portion or all of the common recreation areas.

\section{Distribution of the Proceeds}

Even if the statutes were to permit contraction of the condominium, distribution of the proceeds of condemnation or casualty insurance would be difficult. The statutes commonly provide that in the event

162 See, e.g., Ala. Code tit. 47, \$291(b) (Supp. 1967) ; Fla. Stat. ANN. \$711.05 (1969) ; Md. ANN. Code art. 21, § 120 (1957); N.Y. REAL Prop. LAW $\$ 339-i(2)$ (McKinney 1968); Wrs. Stat. ÁnN. \$230.75(2) (Supp. 1969).

163 See D.C. CoDE ANN. \$ 5-929(d) (1967); Hearings on S. 854 \& H.R. 4276 Before the Judiciary Subcomm. of the Senate Comm. on the District of Colmmbia, 88th Cong., 1st Sess. 26-28 (1963); Hearings on H.R. 4276 Before Subcomm. of the House Comm. on the District of Columbia, 88th Cong., 1st Sess. 26-29 (1963). Brazil has met the problem of partial condemnation by prohibiting the condemnation of a part of a condominum development, although total condemnation is permitted. Law of June 25, 1928, Decree No. 5,481, Act 7 (1928), Colecao das Leis I. 108, Altos do Poder Legislativo (Colecão (legis.)).

164 But see N.Y. Real Prop. Law \$339-i(2) (McKinney 1968); Pa. Stat. AnN. tit. $68, \S 700.802$ (1965).

165 See RoHaN \& Reskin, supra note $15, \S 12.04$, at 12-28. 
of damage or destruction to the development, the proceeds of insurance not used for repair must be divided among all unit owners in proportion to their common interests. ${ }^{166}$ Although these statutes make no provision for the disposition of condemnation proceeds, the courts may require distribution in the same manner as distribution of the proceeds of casualty insurance. This is particularly true in view of the provisions that all unit owners are entitled to share in common receipts in proportion to their common interests, ${ }^{167}$ and because the condemned portions will subsequently be destroyed by the condemning authority.

Such arrangements, however, would be manifestly unfair in a lateral development which could continue to function even if some units were eliminated as a result of destruction or condemnation. If the condominium statutory arrangements were followed, the proceeds would be distributed to all unit owners. Consequently, the owners of the destroyed or condemned units would receive only a small fraction of the proceeds attributable solely to their units and would be left without homes, whereas the owners of the remaining units would receive proceeds although their units remained intact.

While it is obvious that proceeds should be paid to the owners of the eliminated units, it does not follow that they should receive all of the proceeds. The owners of the surviving units, also being the owners of common elements (such as outside walls, roofs, underlying land) which may be taken or destroyed together with units, should be entitled to share in the condemnation awards or insurance proceeds for these common elements. This raises the problem of how to allocate the portion of the proceeds of insurance or condemnation between the units and the common elements. Condemnation awards are normally paid on the basis of the value of the house taken, including the underlying land, outside walls and roofs. Units are, however, commonly limited to merely the interior space of the house and perhaps a fraction of an inch of thickness of the walls, ceilings, and floors, while the rest of the physical portion of the residence constitutes common elements. In such a case, if the owner is to receive an award only for the value of the air space, he may be given very little, ${ }^{168}$ although his air space clearly has some value. Casualty insurance proceeds are paid for the diminution in value of the insured's interest in the property, rather than for destruction of physical portions of a building. Although the value of his air space is reduced by the destruction of the surrounding common

166 Text accompanying note 153 supra.

167 See Alaska Stat. \$ 34.07.380 (Supp. 1968) ; Fla. Stat. Ann. \$ 711.14 (1969); HawaIr Rev. Stat. \$514-10 (1968); N.Y. Real Prop. Law \$339-m (McKinney 1968); OHIo Rev. Code ANN. \$ 5311.21 (Page Supp. 1968).

iós See Alaska Stat. \$ 34.07.012 (Supp. 1968); MIch. Comp. Laws \$ 559.2(a) (1967) ; Tex. Rev. Crv. Stat. art. 1301 (a), \$2(c) (Supp. 1968); Wyo. Stat. ANN. $\S 34-389.8$ (Supp. 1967). 
elements, it may be difficult to measure this loss where the unit owner has sustained very little physical damage.

On the other hand, the owner of the condemned or destroyed unit, who is to be eliminated as a participant in the development, should be compensated by the surviving owners for his interest in the remaining common elements. However, he is compelled to seek compensation for his unit and common interest from two different sources. It is likely that each payor will attempt to minimize its liability by attributing to the property for which it is responsible a smaller portion of the value of the unit owner's totality of property interests. It is therefore possible that the total payments that the unit owner will receive will not equal the amount that he would have realized on the sale of the unit and its appurtenant common interest, absent condemnation.

Where the owner of a condemned or destroyed unit receives a share of a condemnation award or insurance proceeds and is paid by the owners for the interest he assigns in the common elements, he also encounters the problem of apportioning the basis of his unit between the unit itself and the appurtenant interest in the common elements in order to determine taxable gain or loss for income tax purposes. ${ }^{169}$ While both interests are held for the same length of time and are both either long term or short term, it is possible that gain or loss must be calculated separately. The unit is a capital asset pursuant to section 1221 of the Internal Revenue Code, while the interest in the common elements is regarded as used in a "trade or business" and governed by section $1231^{170}$ (resulting normally in ordinary, rather than capital loss

169 INT. Rev. Code of $1954 \S \S 1012$, 1016. See Inaja Land Co., 9 T.C. 727 (1947). For this purpose the unit owner would adjust the basis of his home for the cost of improvements that he made thereto, and, as the owner of an undivided interest in the common elements, would perhaps adjust the basis of his common interest for improvements made by the condominium organization for which he contributed and perhaps reduce his basis by any depreciation which could be taken where the common elements are regarded as used in a "trade or business" because the condominium organization provides services for the co-owners or has commercial space such as recreation areas for which it charges admission. See INT. REv. Code of 1954, § 1016(a) (2) (A).

For similar allocation problems of the developer, see note 145 supra.

170 Gain on the sale of a home is capital gain, while loss is not deductible. See Treas. Reg. $\$ 1.165-9$ (a), T.D. 6712, 1964-1 CuM. BuLl. 106. Gain or loss on the sale of the interest in the common elements to the surviving owners would be governed by \$1231. Losses resulting from destruction or other casualty to the home are deductible as ordinary losses under $\$ 165(\mathrm{~b})$ of the Internal Revenue Code but are included in the $\$ 1231$ netting process and may be treated as capital if there are gains from other \& 1231 transactions. E. Taylor Chewning, 44 T.C. 678 (1965), aff'd per curiam, 363 F.2d 441 (4th Cir.), cert. denied, 385 U.S. 930 (1966) ; Morrison v. U.S., 355 F.2d 218 (6th Cir.), cert. denied, 384 U.S. 986 (1966). Casualty losses on assets used in a trade or business are included in the $\$ 1231$ netting process unless not compensated for in any amount by insurance, in which case the loss is always treated as ordinary loss, InT. REv. CoDE of 1954, $\$ 1231$ (a). There could, therefore, be a different tax treatment for the unit and for the interest in the common elements if no compensation is received at all. If compensation is received but there is a gain on one and loss on the other, the $\$ 1231$ netting process would determine whether ordinary or capital treatment would apply. Id. 
treatment, if sold at a loss) if admission is charged for use of the common facilities or services are provided for unit owners. ${ }^{171}$ Similarly, section 1034 may not be available to defer recognition of a gain with respect to the interests in the common elements where the unit owner acquires a new residence within a year, ${ }^{172}$ but a pro rata depreciation deduction for the common facilities may be allowed. ${ }^{173}$

A converse problem arises whether the owners of the units that are not condemned or destroyed could be entitled to consequential damages upon the elimination of the destroyed or condemned units from the condominium development, since each remaining owner would then be required to pay more maintenance charges for the common areas to compensate for the common charges which would no longer be received from the departing unit owners. Presumably, the damages would be computed by estimating the discounted value of the additional charges over a reasonable period of time. ${ }^{174}$ Alternatively, the remaining unit owners might claim an offset for such damages against the amounts which they would pay to the owners of the extinguished units for the interests surrendered in the common elements.

Each unit's possession of an interest in the common elements raises still other questions for a condominium development in the event of condemnation. Two of the more important questions are whether the condemning authority should make the award to the owners, the board of managers, or both, and whether all should be made parties to the condemnation proceedings. ${ }^{175}$ There is also the additional uncertainty of whether the units will be valued as separate parcels or whether all units will be valued as an entirety. ${ }^{176}$

171 See Treas. Reg. 1.761(a) (1), T.D. 6198, 1956-2 Cum. BuLL. 461. Anderson, 25 N.Y.U. 25TH INST. ON FED. TAX 79 (1967); Note, Condominium-Tax Aspects of Owmership, 18 VAND. L. REv. 1832 (1965).

172 INT. REv. CoDE of 1954, § 1034 refers to the sale of a "principal residence," which may not apply to the interest in the common elements where admission is charged or the condominium organization is otherwise taxable as a business organization. See Anderson, 25 N.Y.U. 25TH INST. ON FED. TAX (1967); Note, Condominium-Tax Aspects of Ownership, 18 VAND. L. REV. 1832 (1965).

173 INT. Rev. CODE of 1954, §167.

174 For analogues concerning consequential damages for increased future assessments and expenses resulting from eminent domain $c f$. Hemmerling v. Tomlev, Inc., 67 Cal. 2d 572, 432 P.2d 697, 63 Cal. Rptr. 1 (1967); Helena Valley Irrigation Dist. v. State Highway Comm'n, 150 Mont. 192, 433 P.2d 791 (1967); and In re Westchester County, 204 Misc. 1031, 127 N.Y.S.2d 24 (1953) where it was held that damages may be limited to the difference in the value of the entire parcel before and after the taking.

175 See Comment, Emintent Domain: Its Possible Effect on the Condominium, 14 Hastings L.J. 327, 328, 331 (1963); RoHAN \& RESKIN, supra note 15, \$12.04[3], at $12-31$.

176 See RoHAN \& RESKIN, stipra note $15, \S 12.04$ [3], at 12-31. 


\section{Affect of Partial Condemnation or Destruction on Mortgages}

The taking or destruction of some of the units will affect not only the unit owners and, of course, those who hold mortgages on these units, but the mortgagees of the remaining units also. This is true because a condemnation or destruction of some units is likely to include some adjoining common elements, such as roofs or outside walls, which are part of the security for mortgages on all of the units. Conversely, if the mortgage instrument is properly drafted, this security may be enhanced by incorporating the interest in the remaining common elements surrendered to the surviving unit owners. Mortgagees may also, under the terms of the mortgage instruments, be entitled to the proceeds receivable by the remaining units with respect to the common elements condemned or destroyed. The net effect of these transactions may be to increase the ratio of the mortgage security to the debt.

The problems outlined above of allocating the proceeds of condemnation or insurance between the units and common elements would also affect mortgagees, who would receive a portion of the proceeds, depending upon the terms of the mortgages. At most, however, the mortgagees could claim that portion of the proceeds allocable to the unit and a share of the proceeds allocable to common elements, calculated in accordance with the interest of the unit in common elements. Since such mortgagees might be entitled to receive only a small fraction of the award, ${ }^{177}$ and would face the problems of allocating proceeds between the mortgaged units and the common elements, ${ }^{178}$ the attractiveness of condominium developments for mortgage lenders would be diminished.

The magnitude of the aforementioned problems would be reduced if a home owners association were utilized instead of the condominium framework. Since each home, including roof and outside walls, could belong entirely to its owner, he would be exclusively entitled to receive condemnation awards. A separate casualty insurance policy could be carried on each unit, instead of a master policy, entitling him, or his mortgagee, to receive all insurance proceeds. He would, therefore, avoid the problem of sharing condemnation and insurance proceeds for the units with the other owners. The proceeds with respect to the common facilities owned by the association would be shared, where appropriate, either equally or according to the participation of each owner in the association, as provided for in the charter and by-laws. Because of the physical separation of the common facilities from the units, there should be little problem of allocating proceeds between a

177 See text accompanying notes 168-69 supra.

178 See text accompanying notes 169-70 supra. 
unit and common property. Similarly, it should not be necessary to provide that any home destroyed should be rebuilt by the other owners or that the association should be dissolved and all homes sold, as provided in the condominium statutes. Absent these legislative restrictions, it should also be possible to provide for the contraction of the development. ${ }^{179}$ While the problem of consequential damages and income taxes may not be avoided, the magnitude of other problems following condemnation or destruction would be greatly decreased.

\section{CoNCLUSION}

No firm conclusion can be drawn to cover all situations in deciding which form is presently more advantageous-the condominium or the home owners corporation. The answer depends upon the locale of the development, the factors which are most important in a particular situation, and whether the problems are viewed from the vantage point of the developer or the unit purchaser.

For the developer of a lateral housing community, the scales generally appear to be tipped in favor of the use of a home owners corporation. This format tends to provide him with greater flexibility in planning the community, and an opportunity to build in sections, using to his advantage his experiences in the earlier ones at each successive stage. There is also less likelihood of onerous blue sky laws requiring the filing of building plans and the completion of all units before any are conveyed, which can be costly and inhibiting to the developer. These advantages, together with the greater ease of obtaining mortgage financing, of controlling the development, and of using leased land would appear to swing the balance in favor of a home owners corporation. Of course, in any given case where the developer can obtain mortgage financing and is not faced with serious blue sky and other restrictions, he may desire to select the condominium form because it may have greater sales appeal to prospective purchasers or because of zoning or other advantages that it may provide.

For the purchaser of a home, the decision may be more difficult. A crucial factor in his choice will be the applicable state laws. On the one hand, despite the drawbacks previously discussed, the condominium may, in a number of states, afford him greater advantages because the condominium statutes provide blue sky safeguards. They protect him in the event of destruction, condemnation, or termination; fix standards for the establishment of common interests and prevent arbitrary changes therein; require completion of the development before conveyance of

179 HANDBOok, supra note 2, at 206-13, 346-50. 
units; and impose architectural controls. Similarly, the condominium form may be desirable to a purchaser because it may create a better climate for the viability of the development by providing greater assurance that assessments will be collectible and that the restrictions and decisions of central management will be binding upon all initial and subsequent owners of units. These safeguards may be lacking for one who acquires a home in a tract association development. In addition, the detailed condominium legislation, geared to homeowners, regulates the functioning of the organization, whereas the tract association may utilize a corporate format not specifically designed for residential subdivisions.

On the other hand, the home owners corporation will provide him with greater independence from the whims and desires of the other owners of homes in the development, will insulate him from liability for personal injuries occurring in the common areas. It can afford greater protection in certain instances and prevent complications in the event of destruction or condemnation of all or part of the development. The owner may also find it easier to refinance his mortgage and to sell his unit. The relative importance of these factors to a prudent purchaser will decide which type of development he finds more attractive.

As a practical matter, it is not possible to consider the overall advantages to the purchaser without also considering the developer. Features that are attractive to a purchaser will result in greater sales appeal and hence will, for that reason, also be attractive to developers. Similarly, advantages to developers will permit more construction at cheaper prices which will benefit purchasers as well. Currently, choice of one mode or the other should certainly not be made in any particular situation without carefully considering all of the factors discussed herein in the light of prevailing circumstances and applicable state law.

Regardless of the overall merits of either format for any particular situation, statutory revisions are desirable so that both of these approaches can be utilized more readily to achieve many of the goals for lateral developments outlined at the beginning of this article. Legislative amendments would give particular help to the many existing condominium units, by offering advantages presently available only in tract associations. These amendments could be made without a change in legal format, avoiding the complications such a change would cause. Such statutory amendments would also be advantageous for high-rise developments and hybrid subdivisions containing both apartment houses and one-family homes. Legislation would also be desirable to cover the existing pitfalls inherent in tract association subdivisions. In this way, both the developers and purchasers will be permitted a choice of the legal form which is most suited to their particular needs, while 
at the same time affording protection to the unit purchasers and assuring the viability of the development.

In order to remove the existing drawbacks of condominium legislation so that this form of home ownership and management can also lend itself more readily to achieving the desired goals in lateral developments, major statutory amendments are required in the following areas:

1. Since uncertainty regarding the enforceability of decisions of central management and of assessments, as well as restrictions imposed by the charter and by-laws, can be an important drawback to the use of home owners corporations, the statutes of any state in which such doubt exists should be amended to provide for enforceability against initial and subsequent purchasers. This change may make the use of home owners corporations generally more desirable for the owners and purchasers of homes, as well as for developers.

2. The condominium statutes should be amended to provide specifically that they apply to lateral as well as to high-rise developments. In addition, all language in the statutes indicating otherwise should be changed. Thus, there should be eliminated from the statutes such phrases as "horizontal developments," the "building," and references to units as consisting solely of "apartments."

3. Equal treatment should be afforded to all lateral developments, whether utilizing the condominium or other format, in platting and subdivision requirements and in the procedures for filing detailed building plans and specifications before sale or conveyance of houses. It would be desirable to permit sale of a unit without requiring the filing of building plans for all other units.

4. The requirements for the completion of all units and common facilities before the conveyance of any should be equalized for condominium and other developments. Consideration should be given to permitting such conveyances provided that the developer posts a satisfactory completion bond covering the remaining units and common facilities. Alternatively, disclosure to purchasers of the possibility of non-completion should be required. Any compulsion that is required should be the same for both condominium and non-condominium developers.

5. Blue sky and other regulations of the offering and sale of units in developments with common facilities should apply equally for condominium and other projects. The obligations and restrictions imposed on unit owners are sufficiently important in all of these types of com- 
munities to warrant similar protection to purchasers and like treatment for developers. Where it is felt that certain requirements are unnecessary, they should be relaxed for both condominium and noncondominium developers.

6. The statutes should be tailored to permit staged development as well as the merger and federation of condominium communities. For this purpose, the decisions of the central entity managing the various federal condominium developments should also be made enforceable against the subsidiary bodies and the unit owners.

7. Condominium legislation should permit the fixing of any equitable basis for determination of the interest, vote, and share of expenses for each unit. The common interest should not be fixed solely according to the original sales price, nor should there be a compulsory tie-in between the apportionment of voting power, sharing of expenses, and interests in distribution of assets. Equalization of voting power and sharing of assessments among all units should be permitted regardless of differentials in values or sizes of units.

This procedure could largely eliminate some of the complications discussed above, resulting from the present statutory requirements for the fixing of interests. In addition, changes in the interests should be permitted in the event of the addition of other units to the development or the contraction, merger, or federation of the community.

These provisions for flexibility would, however, be appropriate only if there is adequate state regulation and protection of unit owners, as well as full disclosure to unit purchasers.

8. Fair apportionment of insurance and condemnation proceeds among the condominium unit owners must be assured. Since original sales prices may not be an equitable criteria, consideration should be given either to distribution on the basis of current value or to allowing courts to determine the distribution of condemnation and casualty insurance proceeds, and to make any other amendments to common interests as they see fit in any given situation.

9. In order to safeguard the saleability of unsold units and to promote effective management, the developer in both types of development should be permitted certain control over the development even after he has sold a majority of the homes. These controls might be limited to physical maintenance and repair, establishment of the amount of assessments and veto power over major structural additions or alterations in the development. It does not have to encompass restrictions on resale of units. The developer should also be allowed relief from his obligation to pay for those common expenses which are 
not incurred by the unsold units. ${ }^{180}$ At the same time, the interests of the unit purchasers should be protected by requiring full disclosure of these facts prior to sale and of the possibility that the developer may rent unsold units.

To offset the conflict of interests resulting from the developer's control of the project while selling units, he should be prohibited from commingling funds of the unit owners with his own, and he should be required to keep detailed, accurate books of account. Moreover, he should be required to post a bond covering his possible liability from mismanagement of the community.

10. Rebuilding of destroyed lateral condominium units should not always be required, and never at the expense of the other owners. The developer should be given the freedom to draft the charter and by-laws so that they can meet the needs of his particular development. If rebuilding is not actually undertaken, the statutes should not require the dissolution of the community and sale of all of the buildings. Instead, contraction of the project should be permitted by the elimination of the units destroyed and the surrender of the interest of those units in the common elements to the remaining unit owners, who should be obliged to pay for these interests.

The condominium statutes should provide similarly for condemnation. Where units condemned or destroyed are to be eliminated from further participation in the development, common interests should be realigned, at least for purposes of sharing future distributions in the event of subsequent destruction, condemnation, or sale. Realignment should be in accordance with the current values of other relevant conditions of the units, such as size.

Since there will now be fewer units to share this burden, the surviving units will be forced to bear an increased share of the expenses of maintaining the common areas. Where a large number of units are eliminated, it may become economically unfeasible to continue the operation of these facilities. The statutes should provide, therefore, that condemnation awards include payment to the remaining unit owners for the discounted value of the increase in common charges, which they may have to bear for a reasonable amount of time due to the decrease in the number of owners sharing the burden of maintenance, offset by the increase in value of their common interests (due to the surrender of interests in such common areas by the owners of destroyed or taken units). In many cases, the surviving unit owners will emerge with a net gain. In any event the owners of condemned units should be compensated in full for the common interests that they 
are forced to surrender. Payments to them should be made by the condemning authority and/or the surviving unit owners in amounts depending on the mathematics of gain or loss to the survivors. ${ }^{181}$ It would similarly be desirable to provide for a like payment to the surviving owners in the insurance policy for the common area, or in the master policy. Since the survivors might not be regarded as possessing an insurable interest in the destroyed units, statutory modification should permit such insurance protection particularly where the condominium format with its broad insurance authorization ${ }^{182}$ is not utilized.

Where both common elements and condominium units insured under the same policy are taken or destroyed, an allocation must be made between the value of the unit and the common elements affected. The statutes might require that such allocation be made by a court of equity, which is specifically granted expanded powers for this purpose, and that the court use expert assistance. The owner of each eliminated unit should then receive a portion of the proceeds of such insurance or awards in accordance with the value of his residence at the time of the destruction or condemnation. The court should also have the power to pay a unit owner a sum greater than that which he might be awarded solely for the value of the unit as legally defined, particularly where the unit consists largely of air space and the physical portions of the residence are common elements. A unit owner should also be paid for the value of his interest in the common elements which he is required to surrender to the owners of the remaining units, while the survivors, as previously discussed, should receive payments for those portions of the common elements which may have been taken or destroyed.

11. Where the condominium framework is abandoned by the unit owners, the sale of all units should not be required. Unit owners should be given the option of retaining their units, although sale might still be required for common facilities.

12. Contraction of a development should be authorized by elimination of units and the reapportionment of appurtenant common interests among the owners of the remaining units in equal shares. Here, too, such allocation should be permitted on the basis of present value of

181 For example, if the owner of a condominium unit surrenders a common interest worth $\$ 500$ and the survivors have increased common charges capitalized at $\$ 300$, the relinquishing owner should receive $\$ 500-\$ 300$ from the condemning authority and $\$ 200$ from the survivors, who would be paid nothing by the condemnor. If the common interest were worth $\$ 300$ but the additional charges to the survivors were capitalized at $\$ 500$, the condemning authority would pay $\$ 200$ to the survivors and $\$ 300$ to the owner of the condemned unit.

182 Condominium statutes generally permit management to insure the units. See, e.g., N.Y. REAL PROP. LAW \$339-bb (McKinney 1968); PA. STAT. ANN. tit. 68, $\S 700.801$ (1965); W. VA. CODE ANN. § 36A-8-1 (1966). 
the surviving units or other equitable arrangement, rather than requiring a redistribution according to common interests based on original sales prices.

13. The statutes in all states should limit or eliminate the liability of unit owners in condominium developments for injuries or property damage occurring in the common areas. At the same time, liability insurance coverage might be required, as in the case of motor vehicles, in order to protect the right of those injured. This arrangement could be an important contribution in equalizing the benefits of home ownership in condominium and conventional developments.

14. Legislative clarification should be provided so that the use of the condominium framework does not result in different treatment for zoning purposes. Some of the requirements of the multiple dwelling codes might be made applicable to lateral condominiums, depending upon the physical proximity and interdependence of units and the degree of maintenance and regulation of units provided by central management.

15. In order to achieve better utilization of land resources, statutory permission should be granted for condominium developments utilizing leased lands. The unit owner should be protected against foreclosures by the fee owner resulting from default by other unit owners in payments needed for ground rents. This could be accomplished by providing that such foreclosure be limited to the delinquent units which should remain as condominium units, and that the proceedings do not affect the continuation of the condominium framework.

16. The statutes should make it clear that common elements may be limited to those areas which are commonly used. At the same time, the obligations imposed by statute upon central management for repairs, maintenance, and services should be limited to the common areas, with options to the unit owners and developers to expand the scope of central management where desired. Greater freedom should be granted to unit owners to improve the units without requiring the consent of other owners, where authorized by the condominium instruments.

The statutory changes outlined in the preceding paragraph will result in many benefits. Foremost is the greater independence of unit owners and their decreased liability to contribute for services and maintenance regarding such items as unit walls and roofs used exclusively by another owner, but which are currently required by law to be incorporated as part of the common elements. Additionally, condominium units will thereby become more attractive investments to mortgage 
lenders as well, since there will be less fear that a mortgagee who forecloses will be faced with assessments for repair and services that will essentially benefit only other units. The greater independence of each unit will also mean that its value and adequacy as security for a mortgage loan will be far less contingent upon the unpredictable management efficiency of the condominium organization.

Narrowing the scope of common elements to those common in fact may make it more palatable for lenders to limit their mortgages to cover units only, leaving the common elements to be covered by a separate mortgage. This limit will facilitate financing improvements to the common elements by mortgagees in order to mortgage the common areas. It will also have the effect of protecting the unit owner from demands of his mortgagee to repair common elements which he is powerless to carry out.

17. The appeal of condominium units to mortgage lenders can be enhanced further by a statutory provision that if the condominium framework of the development is terminated, the mortgage may continue in force upon the unit at the option of the lender. The units may thus meet the long term investment goals of lenders, particularly since a substantial portion of the loan will probably have been paid off by the time the condominium format is abandoned. 